\title{
Disciplinarity and Transdisciplinarity in the Study of Knowledge
}

\author{
Jay Hillel Bernstein \\ Kingsborough Community College, \\ City University of New York, Brooklyn, NY, USA
}

\author{
Jay.Bernstein@kbcc.cuny.edu
}

\begin{abstract}
Scholarly inquiry about the nature and significance of knowledge has been shaped by disciplinary traditions and priorities that define "knowledge" differently and result in disconnected literatures. In the mid to late twentieth century, library science educator Jesse Shera sought to bridge the conceptual gap between epistemological and sociological approaches to knowledge in proposing a new discipline he called social epistemology. Around the same time, long-term projects by the economist Fritz Machlup and the physical chemist turned philosopher of science Michael Polanyi did not merely combine existing disciplinary approaches but transcended conventional frameworks for conceptualizing knowledge. These scholars can be viewed in retrospect as bringing to the study of knowledge the germs of a transdisciplinary approach. The concept of transdisciplinarity gained traction only after these authors produced their works and has been applied mainly to scientific and technological topics such as climate change, nanotechnology, and sustainability. However, such an approach is highly applicable in studying the meanings, uses, and roles of knowledge in an environment that has changed with the advent of computer-enabled communication networks. Transdisciplinary accounts of knowledge ought to foster a dialogue between liberal arts and applied, client-oriented disciplines.
\end{abstract}

Keywords: theory of knowledge, social epistemology, knowledge management, sociology of knowledge, disciplinarity, interdisciplinary approach to knowledge, transdisciplinarity, Fritz Machlup, Michael Polanyi, Jesse H. Shera

\section{Introduction}

Many have observed that knowledge is central to the purposes of the academy and libraries. For example, James J. Duderstadt (2000, pp. 8-9), a university president, aptly described the connection between universities and knowledge when he wrote, "Our universities exist to be repositories, transmitters, and creators of human heritage. They serve as guardians and creators of that

Material published as part of this publication, either on-line or in print, is copyrighted by the Informing Science Institute. Permission to make digital or paper copy of part or all of these works for personal or classroom use is granted without fee provided that the copies are not made or distributed for profit or commercial advantage AND that copies 1) bear this notice in full and 2) give the full citation on the first page. It is permissible to abstract these works so long as credit is given. To copy in all other cases or to republish or to post on a server or to redistribute to lists requires specific permission and payment of a fee. Contact Publisher@,InformingScience.org to request redistribution permission. knowledge." R. David Lankes (2011, p. 303) makes a similar claim about libraries when he states in a system of graphs that "the mission of librarians is to improve society through facilitating knowledge creating in their communities," and that "libraries are in the knowledge business [and] therefore the conversation business" since "knowledge is created through conversation." 
Given that knowledge is an ideal to which these institutions are dedicated, what scholarly approach must we use to study knowledge itself, and how should such an inquiry proceed? What research has been done on the subject, and where would we find it?

Knowledge is not an ordinary subject for research. In a sense, all academic discourse is or relates immediately to knowledge, so trying to isolate it as a containable category for observation and analysis seems as paradoxical as M. C. Escher's lithograph depicting a hand drawing another hand. Scholarly writing about knowledge does not cohere as a body of literature because authors tend to represent different disciplines that have such differing stakes in knowledge that they appear to lack a common ground even on the meaning of the word "knowledge."

Surveying the array of academic disciplines, it is apparent that no single discipline exists that specifically studies knowledge. Two contemporary fields we might consider as focusing on knowledge as a subject matter are knowledge organization (KO) and knowledge management (KM). Neither is a full-fledged discipline, though both have professional societies, conferences, and journals and are the subject of graduate level courses. KO, a specialization in library and information science (LIS), contributes to our understanding of the nature and significance of knowledge and may be heavily implicated in theoretical debates about the nature of knowledge (Hjørland, 2013), but it is not in and of itself the study of knowledge, only its organization through cataloging, classification, indexing, thesauri, and other aspects of bibliographic control, such as the relationships between works and instantiations (see Hjørland, 2003; Smiraglia, 2002). The burgeoning field of KM is the source of most recent literature on knowledge. Contributors to this literature include professional managers and consultants as well as faculty members from schools of business administration and management, departments of organizational studies, and institutes of policy studies. Although the KM literature includes significant contributions on the conceptualization of knowledge (Alavi \& Leidner, 2001; Blackler, 1995; Spender, 1996; Stenmark, 2001), it, too, is not in itself the study of knowledge but rather a "set of processes that create and share knowledge across an organization to optimize the use of judgment in the attainment of mission and goals" (Townley, 2001, p. 45).

Ultimately, no discipline can "own" the subject of knowledge as a problem for inquiry because knowledge belongs to all scholars and inquirers. Part of the problem, one can argue, lies in the very segmentation of knowledge into disciplines. Therefore, an approach to knowledge should be developed that transcends the limitations of disciplinary perspectives altogether by viewing the study of knowledge as a transdisciplinary undertaking. As we shall see, scholars have long recognized shortcomings in traditional disciplinary approaches to knowledge, and it is possible to trace in their efforts a genealogy of transdisciplinary knowledge studies. A newly re-imagined project on knowledge could make connections visible between various wings of knowledge research (e.g., managerial vs. liberal arts, deconstructionist vs. traditionalist) that seemingly coexist peacefully through benign neglect.

The purpose of this essay is to examine the problem of studying knowledge within educational and scholarly settings through its connection with academic disciplines. It begins by comparing and contrasting the ways knowledge is approached in philosophy and sociology. It then describes early attempts to transcend disciplinarity in studying knowledge, and touches on the matter of disciplinarity as a problem and subject in its own right. The essay proceeds by describing a movement toward transdisciplinary in research and education that has been used in science and technology but could be applicable to the study of knowledge. The centerpiece of the essay is an analysis of two scholars, Fritz Machlup and Michael Polanyi, seen as pivotal to attempts to transcend disciplinary thinking in studying knowledge. The essay then examines their legacy by surveying recent studies in knowledge management (including informing science) as well as other individual approaches. The essay concludes with a discussion of future prospects for the transdisciplinary study of knowledge. 


\section{Epistemology: The Philosophy of Knowledge}

Questions about the ultimate nature, purpose, and value of knowledge are philosophical questions, so it is necessary to start our discussion of the academic compartmentalization of thought about knowledge with philosophy. Long before the advent of the modern university with its disciplines and departments, philosophers have been asking what it means to know, how we acquire knowledge, and how we know that we know. Along with metaphysics, ethics, logic, and aesthetics, epistemology - the study of knowledge - is one of the five basic categories of philosophical inquiry.

Epistemologists study the basic and fundamental aspects of the meaning and justification of all knowledge. Traditional epistemology deals with the nature, sources, and extent of knowledge. The philosophical analysis of knowledge is about fact, truth, justification, evidence, doubt, external reality (including the existence of other minds), and cause and effect (see, e.g., Alcoff, 1998; Lucey, 1996). Some philosophers think that the aim of epistemology is to investigate the relationship between knowledge and objective reality, while others assert that the very notion of "objective reality" outside one's own concept of it needs to be examined critically. It seems unlikely that any proposed baseline of reality will be acceptable to all persons.

Knowledge is viewed by philosophers as a special kind of belief or opinion. Therefore, a fundamental question in epistemology is what criteria differentiate knowledge from other beliefs and opinions. That is, what criteria must be satisfied for a belief or opinion to count as knowledge? The so-called classical (or traditional) notion of knowledge in modern philosophy equates knowledge with "justified, true belief." However, in a short article, Edmund Gettier (1963) demonstrated that justified true belief may not be knowledge, since lucky guessing may be involved and correct but lucky guesses do not qualify as knowledge. For example, if a man drives in an area where, for some reason, and unbeknown to him, many papier mâché replicas of barns dot the countryside, does he know he has seen a barn if he correctly identifies a real barn by chance (Pritchard, 2009, p. 12)? The assertion that he has seen a barn would be true and justified inasmuch as the driver saw what looked like barns, but in this instance it is only a lucky guess, not real knowledge. Could an assertion be justified but false? This is just a single example of the kind of question an epistemologist would ask. Besides truth and justification, two more conditions of knowledge identified by the prominent contemporary epistemologist Keith Lehrer (1990) are acceptance and justification without falsity. The latter seems on the surface to be covered by the notion of justification, but Lehrer's analysis shows it to be a separate factor.

While epistemologists may probe the implications and consequences of real world situations from history, current events, or everyday life, the above example demonstrates a preferred method of advancing theories through the use of thought experiments, in which hypothetical and often improbable, even outlandish scenarios are analyzed for their logical plausibility, consistency, and implications. Arguments often take this form: If this is the case, then it follows that that must also be the case. The purpose of this work, which can seem fanciful on the surface, is to push back against commonsense assumptions about knowledge using logical analysis. Duncan Pritchard's (2009) text includes many such arguments demolishing common fallacies people accept as truisms about the nature of knowledge. The sticking points seem to hinge on the purported knower's reasons for certainty, but any aspect of knowledge can be subject to attack. It is no wonder that a significant strain of philosophical thought argues for skepticism that knowledge is possible. Certainly, logical analysis may cause one to question and ultimately discard many conventional assumptions and received popular opinions about the nature of knowledge.

Knowledge as studied by philosophers is idealized. Moreover, according to Barry Allen (2004, p. 5), philosophers (not only those who specialize in epistemology) have idealized certain kinds of knowledge: "a view from nowhere, knowing things as they are, not as they affect another." Allen 
describes the kind of knowledge adored by philosophers (and probably most other purist scholars) as "perfectly useless and beautifully true" (p. 1). Steve Fuller (2002, p. 16), likewise, has mentioned "the contemplative, even ethereal quality of classical conceptions of knowledge." Philosophers, who analyze and speculate about concepts and theories, largely created the tendencies prevalent among academics in all subjects and disciplines to prefer to look at knowledge in a vacuum and at knowledge domains as objects of contemplation and connoisseurship.

This view of knowledge can be said to have shaped many if not all pure liberal arts disciplines in the humanities and social sciences. "Pure" in this context means they are not affected by real world applications and with them a need for real-world results. The philosophical approach described by Allen (2004) can be equated with what is referred to, whether derisively or longingly — or both — as the "ivory tower." The scholar's beautiful and useless knowledge contrasts against knowledge that is useful somehow and that may not be beautiful but could even get ugly as we leave the ivory tower and enter the streets and jungles of the real world. Unless a chasm separates knowledge and other modes of thought, then if we accept this concept of knowledge as perfect and unsurpassed, knowledge must shade gradually into other imperfect products of human cognition.

\section{The Sociology of Knowledge}

Social scientists, led by sociologists, began in the nineteenth century to take the study of knowledge outside the ivory tower by studying ideology in the context of knowledge (Curtis \& Petras, 1970). Such a topic requires one to shift from a purely philosophical, idealistic, or scientific view of knowledge conforming to classical notions of truth to one centered on group action caused by or related to a sense of certainty or being informed. For example, mass panics, uprisings, and revolutions could have been caused by the spread of rumors. They were related to social control, dogma, and charisma. What the sociologist accepted as "knowledge" for analysis using social science methodologies might be just common belief, opinion, or even misinformation or delusion, but it was guided by a sense of certainty.

Although sociological ideas predate the formal beginning of sociology as an academic subject (Curtis \& Petras, 1970), the sociological concept of knowledge seems to follow Emile Durkheim's (1895/1938) notion of social facts, which, according to him, are forces of social control, organization, and coercion. Because they occupy a different plane of reality than physical, biological, or psychological facts, they require sociological methods to investigate them.

The sociology of knowledge, in the words of Peter L. Berger and Thomas Luckmann (1967, p. 3), "must concern itself with whatever passes for 'knowledge' in a society, regardless of the ultimate validity or invalidity (by whatever standard) of such 'knowledge'." For purposes of sociological analysis, according to them, knowledge is based on the sense of reality. Therefore, they emphasize, "the sociology of knowledge is concerned with the analysis of the social construction of reality" (Berger \& Luckmann, 1967, p. 3). The notion of socially constructed reality is uncontroversial in some instances: the vice-president of a company is vice-president by virtue of having been appointed to that position by someone authorized to bestow that title and have it recognized by others. More controversial versions of constructivism would claim, for example, that one is male or female by virtue of social consensus and the decisions of socially recognized experts rather than biological criteria (Fuss, 1989). "Truth" itself in this more radical theory is socially negotiated, and expertise is determined by social processes, through power, persuasion, and influence rather than by objective measures, and "objectivity" is a just a hollow, self-justifying claim, a means of gaining the rhetorical upper hand and setting the terms for discussion. Since knowledge concerns human apprehension of truth and facts, this notion of social fact, whether applied conservatively or liberally, affects the analysis of knowledge. The more extreme versions of constructivism (e.g., Haraway, 1991; Latour \& Woolgar, 1979/1986) raise the question of whether 
truth is optional (Hacking, 1999). Constructivism (sometimes also known as constructionism) not only covers a range of intensities but is connected to different kinds of claims about what is constructed (Sismondo, 1993). The many modes of constructivism/constructionism are evidenced in the 40 chapters and 800 pages of the Handbook of Constructionist Research (Holstein \& Gubrium, 2008).

Unlike epistemologists, who study the fundamental nature of knowledge using logic and analysis, sociologists study knowledge empirically in its construction or organization, development, distribution, deployment, perpetuation, and uses, for example, in making decisions or in creating social divisions and categories. As such, knowledge is not understood, as it is by traditional epistemologists, in terms of a logically justified concept of truth, but rather in terms of "mental productions" regardless of their epistemological justification (Maquet, 1949/1951, p. 4). Such notions may not be scientifically or analytically factual but generally are characterized by people's sense of absolute certainty about them. (People can of course be absolutely certain of things that are absolutely false, a phenomenon analyzed by the psychologist Thomas Gilovich, 1991, in an aptly titled book, How We Know What Isn't So.) Lacking a more precise concept of knowledge, the sociologist can only examine claims of knowledge to see how a sense of reality is constructed.

Gender and illness are among the social phenomena commonly understood by sociologists to be part of social reality. As such, knowledge about these domains is knowledge of social constructs. Such a theoretical stance, taken to its logical conclusion, leads to a situation where any sincere and unwavering but false belief is accepted as knowledge. Imagine a woman who claims she is a man, lives as a man, and convinces others she is a man. Is the belief she is a man knowledge? In this instance, the answer could depend on how one views the truth or reality of gender: The subjective, lived experience or the outward expression of gender could override chromosomal or anatomical realities. But a similar question could be asked about the belief that a person who receives a diagnosis of and treatment for cancer but who has no cancerous cells in his body has cancer. If whatever people believe is knowledge, then this belief is knowledge. The patient may be reasonable in trusting the diagnosis of the person he consulted, and he may experience all the anxieties and other difficulties of being a cancer patient, but however the diagnosis was made, it was inaccurate and erroneous. To the extent that accuracy and its opposite, error, are factors in determining what knowledge is, an inaccurate and erroneous belief is not knowledge but nonknowledge (Bernstein, 2009a, 2009b).

For some social scientists, the distinction between belief and knowledge is irrelevant, as they view their goals as showing the connections between knowledge (or belief) and actions and practices, rather than determining the truth value of assertions (Pelto \& Pelto, 1997). But the truth value of assertions about social facts can be highly consequential, for example, in historical narratives.

Both philosophers and sociologists are concerned with certainty, but they mean different things by it. Philosophers ask how one can be certain of something: What are the proper, appropriate grounds for certainty? Sociologists ask what causes people to be certain of something in a particular situation: What criteria do people use to assure them of certainty, to accept something as a fact? The question of how knowledge claims are evaluated is not the normative one of how knowledge claims should be evaluated, as it is for epistemologists, but rather an empirical one of how people in a given context actually go about evaluating or justifying a knowledge claim.

Clearly, traditional epistemologists and sociologists mean two different things by the word "knowledge." More specifically, the standard for acceptability as knowledge is far lower for sociology than it is for epistemology. Since constructivist sociologists consider knowledge to be any belief one can justify, uphold, and share, where, if at all, does the sociologist draw the line between knowledge and belief? While sociologists have succeeded (in the view of many) in cast- 
ing doubt on the notion of objective knowledge and have shown how knowledge itself is socially constructed, traditional epistemologists can justifiably brush off all sociological work on "knowledge" that does not differentiate between logically or empirically verifiable beliefs and other claims by saying "that's not knowledge." Indeed, advocates of more traditional epistemologies have expressed annoyance at the sociologists' fast and loose use of the word "knowledge" to describe logically and empirically unjustified beliefs in pointing out why truth matters (Benson \& Stangroom, 2006). The disagreement became a flashpoint in a "culture war" that that flared in the 1990s, focused on issues of the validity of alternative perspectives and viewpoints and the relativity of all knowledge as situated (see Gross \& Levitt, 1994, Haraway, 1991).

The above discussion is not intended to suggest that sociologists are the ones arguing that whatever anyone thinks or asserts is knowledge while epistemologists hold on to more traditional notions of knowledge, accepting the reality of the existence of the external world and the validity of the scientific method. These philosophical positions are not necessarily associated with the individual disciplines of philosophy and sociology. For example, John R. Searle (1995), renowned for his books on the philosophy of mind and language, has advanced a moderate version of social constructivism carefully differentiating between institutional facts that rely on consensus and brute facts that are true whether or not humans know or accept them.

As early as the 1940 s, the insights raised by the sociologists had caught the attention of a traditional philosopher, Arthur Child (1941, 1947), who, though not specifically an epistemologist, labored to reconcile sociological and philosophical concepts about knowledge, contrary to other philosophers (e.g., Hinshaw, 1943) who saw only epistemological confusion in the sociology of knowledge. Child's work was soon followed by studies by sociologists such as Irving Horowitz (1951/1961) and Jacques Maquet (1949/1951) also pondering a rapprochement between sociology and epistemology. These authors raised the prospect of a view of knowledge mutually compatible to social scientists and philosophers interested in the absolute foundations of knowledge that could yield cooperation and collaboration.

Some contemplated transcending sociology to create a new science of knowledge. One could even suggest that sociologists considered challenging philosophy's dominance as the leading discipline studying knowledge. As early as 1940, the Polish sociologist Florian Znaniecki (1940/1970, p. 308) bemoaned the term "sociology of knowledge" as "unfortunate," since "systems of knowledge, or theories ..., are obviously not social systems." What was needed, he thought, was a "fully constituted 'science of knowledge"" parallel to sociology and linguistics, which could inductively analyze and compare systems of knowledge both historical and presentday, viewing them as empirical realities.

\section{Shera's Social Epistemology}

Such ideas were also on the mind of Jesse H. Shera, a leading LIS educator who, in the 1950s, began planning a new science of knowledge. Over several publications, he developed the notion of social epistemology (crediting the term's coinage to his early co-author Margaret Egan) to refer to a proposed new venture, distinct from the sociology of knowledge and dedicated to "the study of those processes by which society as a whole seeks to achieve a perceptive or understanding relation to the total environment - physical, psychological, and intellectual" (Egan \& Shera, 1952, p. 132). Social epistemology was intended to create a needed "framework for the investigation of the entire complex problem of the nature of the intellectual process in society" (Shera, 1972, p. 112). Equally, it was intended:

to lift the study of intellectual life from that of a scrutiny of the individual to an inquiry into the means by which a society, nation, or culture achieves understanding of the totality of stimuli that act upon it. The focus of this new discipline should be upon the pro- 
duction, flow, integration, and consumption of all forms of communicated thought throughout the entire social fabric. (Shera, 1972, p. 112)

Perhaps Shera hoped to surpass or usurp the sociology of knowledge and co-opt it into his own agenda, since he envisioned social epistemology to be "truly interdisciplinary," drawing on "sociology, anthropology, linguistics, economics, the physiology of the human nervous system, psychology, mathematics, and information theory, to name but a few of the most conspicuous areas" (1972., p. 113). Although he aimed at a scientific study of knowledge, Shera denied that social epistemology was a social science, and his approach to knowledge should probably be considered humanistic, following in the tradition of literary and philosophical scholarship rather than a social science research model. The latter requires the researcher to take into account concepts about populations, units of analysis, data acquisition procedures, and metrics. The different general approaches to knowledge in humanities and social science disciplines, as described by the educational psychologist J. G. Donald (1986), illuminate the predicament Shera faced in wanting to use humanistic paradigms and methodologies (such as they are) to process social science materials. Donald refers to studies by Dorothy Ross (1979) and Laurence Veysey (1979) on the development of social sciences and humanities scholarly professions in the context of the evolving American university and Harry Broudy's (1977) essay on types of knowing. She observes, "Because the humanistic disciplines are concerned with phenomena that do not have immediate referents, humanistic truth involves something other than scientific validity .... The emphasis placed on original or divergent thinking leaves truth dependent upon individual critical judgments" (Donald, 1986, p. 276). As already mentioned, the social sciences have a humanistic heritage, but social scientists "appear to have a particular opportunity for validation through general agreement .... The models which social scientists create can be tested and verified and their logical structure can therefore be defined or at least represented" (Donald, 1986, p. 276.).

Social epistemology's primary object of study was knowledge, not society; nor was social epistemology a behavioral science. In differentiating social epistemology from sociology, Shera noted that the sociologists "have directed their attention toward the behavior of men in groups, [but] have paid scant heed to the intellectual forces that shape social structures and institutions" (Shera, 1972, p. 112). Shera wanted social epistemology to fill a gap by providing a perspective obverse to that of the sociology of knowledge. Though he referred to social epistemology as a new discipline, he clearly viewed it as the epistemological foundation for the superordinate discipline of LIS, which was open to social science concepts and methodologies.

John M. Budd (2002), who has critically analyzed Shera's contributions on the subject, finds that Shera did not exclude any assertion or claim as being knowledge. He is unconvinced by Shera's denial that social epistemology shares sociology's permissive view of knowledge. According to such a view, mere affirmations of truth, and not just those affirmations that are independently true, justified, and verifiable, count as knowledge. Finding that Shera accepted sociology's view of the extent of knowledge, despite claims to the contrary, Budd appears to conclude that Shera's vision for social epistemology puts too much emphasis on the sociological perspective. Budd's analysis raises the concern that in trying to strike a middle course in approaching a problem as complex as knowledge from multiple angles, a preference for any given disciplinary approach is bound to appear limited or biased to those who do not share that perspective.

\section{Disciplinarity as a Problem}

Shera's program for an interdisciplinary synthesis of approaches in studying knowledge, and the apparently irreconcilable differences in the epistemological and sociological approaches to knowledge, bring into focus the subject of disciplinarity itself as a problem that needs to be examined in the context of how it shapes people's outlook on knowledge (see Dabars, 2008; Klein, 1996; Messer-Davidow, Shumway, \& Sylvan, 1993; Shumway \& Messer-Davidow, 1991; 
Turner, 2000). The disciplines, as both intellectual and social constructs, are pillars in the organization of the academy and in the literature. As such, disciplinarity, which may be defined as the compartmentalization of scholarly research, labor, and communication into bureaucratic units, is crucial in understanding the organization of knowledge, especially as it relates to higher education and the cultural record.

At the most obvious level, the disciplines confer institutional identity in an organization in terms of a departmental address and expectations in terms of curricular responsibilities. At a deeper level, part of what defines a discipline is how it approaches or relates to knowledge, including what it accepts as knowledge, and where it draws a line beyond which it does not admit something as proper knowledge. In looking at knowledge, the different disciplines disagree on which points are crucial and which are inconsequential, and they emphasize different processes of knowledge validation. Education scholar Janet G. Donald (1995, p. 7) asserts that "the method by which knowledge is arrived at in a discipline, its process of validation, and the truth criteria employed in that process are essential to the definition of the discipline." Each discipline will only see a small part of a larger picture.

A matrix of disciplines has evolved, carving up intellectual spaces into curricular and bureaucratic domains, with specific methodologies, paradigms and other conceptual toolboxes, and inherited problem areas. These disciplines maintain their legitimacy through inertia and may not be fit to tackle problems that have recently arrived on the horizon (Wallerstein, 2004). The major mode of adaptation of disciplines is subdivision into smaller specialties (Becher, 1989).

A discipline, according to Michael Finkenthal (2001, pp. 4-5), "is more than a field of intellectual endeavor defined by the object of research. It also implies the ability to transfer knowledge in an 'objective' way, that is, in such a way that anybody in possession of certain tools can understand it, anywhere and at any time. That is because within a discipline meaning is conserved." One's overall way of thinking is constrained by what Finkenthal (2001, p. 3), calls disciplinarian thinking. Disciplinarian thinking can lead to disciplines becoming "separate domains of discourse, largely 'walled off' from connections to and feedback from outsiders" (Kline, 1995, p. 198). This enclosure leads to a sense of territoriality about which topics and approaches are the rightful property of a discipline, as well as a loose hierarchy of priorities, with some topics considered unfit for consideration. The parameters and objectives of disciplines are often determined by professors at major Ph.D.-granting universities who have written programmatic statements (Townsend, 2013). Success and recognition depend on achievements pertinent to the goals and values of one's own discipline as defined by core texts. Any accomplishments outside one's discipline's perceived mission could raise questions about a scholar's interests and loyalties and could cause the scholar not to receive full credit for his or her work.

Disciplinarity, besides providing institutional identity, lends one an affiliation at a deeper level of identity as a scholar (see Messer-Davidow et al., 1993). Each discipline has its own intellectual rubric that one acquires through study, training, research, and mentoring. By receiving certification, publishing, receiving employment in, and teaching a discipline, one gradually comes to internalize disciplinarity by viewing one's own professional identity in terms of membership in the discipline. Disciplinary thinking can become pervasive when one starts viewing and speaking about everyday matters in terms of disciplinary concepts and priorities.

The need to affiliate and identify has long been recognized as a basic psychological drive, especially among those who yearn for achievement and acclaim (McClelland, 1953). There can be significant psychic investment in disciplinary affiliation (Shumway, 2003); one gains a sense of self-worth and fulfillment by identifying with a discipline. In modern academia, scholars view their discipline more than the institutions that employ them as the source of their affiliation and professional identity (Anderson \& Murray, 1971). The separate discursive spaces produced by 
disciplines result in insularity, which has drawbacks but which can also result in the "the creation of new problems and solutions, new materials and tools, new texts and new interpretations that would not be produced by society at large" (Shumway, 2003, p. 98).

\section{Social Epistemology and Disciplinarity}

Shera, a mid-twentieth century library educator liminally situated betwixt and between the major academic disciplines, proposed an interdisciplinary science of knowledge out of dissatisfaction with the shortcomings he perceived in the approaches to knowledge endemic in existing disciplines. It appears that the very phenomenon of disciplinarity - the division of research into disciplines each with their own personnel — led to the predicament to which Shera (1972; Egan \& Shera, 1952) proposed social epistemology as the solution. Moreover, his concern was similar to that voiced earlier by Znaniecki (1940/1970): There was no science of knowledge-not a sociology of knowledge predicated on the conceptual framework of sociology (involving social action, socialization, social institutions, etc.), but an entirely separate discipline in which knowledge was the focus, and in which conceptual frameworks adopted specifically for the study of knowledge could be devised. As an LIS educator, Shera prioritized the graphic record rather than other forms of communication. Approaches in the evolving mix of librarianship, or library science, bibliography, documentation, and information science that over time converged as LIS (see Rayward, 1983), would, Shera anticipated, pave the way for progress in social epistemology.

Social epistemology was a response to a gap in the literature in the approach to knowledge by the epistemologists and the sociologists. Similar gaps had also been noticed by Donald T. Campbell (1969) in another early critique of disciplinarity, which theorized that the individual disciplines were "arbitrary composites" and warned of a "redundant piling up of highly similar specialties, leaving interdisciplinary gaps" (p. 328.). Characterizing the disciplines as "ethnocentric," he was an early writer to call attention to the parochialism and chauvinism of disciplinary thinking, which can lead to a hall of mirrors effect in which scientists compare their work only to others who share the same frame of reference. While interdisciplinary cooperation and planning was common in universities by the 1950 s, recognition of the limitations of disciplinarity was only beginning to emerge in Shera's time.

Shera's social epistemology, devised as a new way of approaching knowledge, was one of a few projects attempting to circumvent and transcend disciplinarity in tackling a subject that, because of its unique position, could not be handled by a single discipline - neither philosophy, nor sociology, nor any other discipline in existence. Shera's home discipline, library science, provided a different angle from philosophy and sociology that offered an intriguing viewpoint as an applied discipline focused on the selection, acquisition, description, organization, management, and provision of access to documents on all subjects for research, study, inquiry, or other purposes.

Shera framed his work in the context of education for librarians as providing a conceptual basis for research, teaching, and thinking in that profession. At the same time, he wanted social epistemology to affect the thought of scholars and intellectuals more generally, outside the library profession. But few people then or later seriously thought that library (and information) science was central to debates about knowledge, even if they agreed that concepts of and practices surrounding knowledge are at the core of library work and the raison d'etre of the library as an institution. (On the curious relationship between theory and practice in LIS see Carlin, 2009).

Although Shera had the audacity to name his approach social epistemology and proclaim it a new discipline, he did not pursue the subject further by writing an extended text on it after he had opened up the ground for it. Shera and his social epistemology were recognized by scholars in the LIS field but made so little impact outside that field that when the term was reintroduced after his death by philosophers (most notably Steve Fuller and Alvin Goldman), the authors were initially unaware that the term had ever been used before in the literature (Zandonade, 2004). Fuller and 
Goldman have since gone on to prominence developing their own schools of thought regarding social epistemology and have meant somewhat different things by it. They even founded dueling journals, Social Epistemology and Episteme. Ironically, the fate of Shera's social epistemology would itself make for an interesting case study in social epistemology. Nevertheless, Shera's awareness of the need for a new discipline about knowledge can be seen as the beginning of a new kind of approach to knowledge, one that does not merely combine existing disciplinary approaches in focusing on a problem but that attempts, however unsuccessfully (Budd, 2002, 2004), to reconstruct the study of knowledge by thinking outside the limits of all disciplinary perspectives. In a sense, his social epistemology was transdisciplinary before there was a word for it.

\section{Transdisciplinarity}

The first recorded use of the word "transdisciplinarity" occurred in a seminar on interdisciplinarity in universities held in 1970 at the University of Nice and sponsored by the Organisation for Economic Cooperation and Development in collaboration with the French Ministry of Education (Jantsch, 1972a, 1972b; Klein, 2000b). The Austrian astrophysicist Erich Jantsch provided the word's first definition as "the co-ordination of all disciplines and interdisciplines in an education/innovation system on the basis of a generalized axiomatic (introduced from the purposive level down) and emerging epistemological ('synepistemic') pattern" (Jantsch, 1972b, p. 106).

The term rarely appeared in the literature until 1994 when the First World Congress of Transdisciplinarity was convened at Convento de Arrábida, Portugal. The congress resulted in the adoption of the Charter of Transdisciplinarity (http://ciret-transdisciplinarity.org/chart.php) edited by Lima de Freitas, Edgar Morin, and Basarab Nicolescu. That year also saw the publication of The New Production of Knowledge (Gibbons et al., 1994). In this landmark text, Michael Gibbons and his collaborators Camille Limoges, Helga Nowotny, Peter Scott, Simon Schwartz, and Martin Trow (1994) introduced readers to a new vocabulary focused on the idea of context of application, defined, as it pertains to research, as "problem solving and the generation of knowledge organised around a particular application ... [including] the milieu of interests, institutions, and practices, which impinge on the problem to be solved" (p. 167). Transdisciplinarity then was defined by the authors as "knowledge which emerges from a particular context of application with its own distinct theoretical structures, research methods, and modes of practice but which may not be locatable on the prevailing disciplinary map" (p. 168). With the publication of the Gibbons et al. text and the Charter of Transdisciplinarity, interest in transdisciplinarity has burgeoned as an educational approach related mainly to socially responsible science and technology (see Somerville \& Rapport, 2000).

Transdisciplinarity is best understood as a subcategory of the more inclusive interdisciplinarity that has branched off and developed its own rhetoric (Klein, 2009). This rhetoric can easily be read to suggest that transdisciplinarity represents an utterly novel approach heralding a complete break from all previous disciplinary thinking and organization of research and pedagogy. However, its roots can be seen in the writings of various earlier scholars. This essay explores some of these roots in detail by focusing on a few key individuals, but others have anticipated parts of the transdisciplinary agenda.

Transdisciplinary research involves work in both academic and nonacademic settings and it includes the inputs of participants or subjects of studies on an equal footing with those of investigators. Topics described as being too complex for disciplinary or even interdisciplinary research, ranging from global climate change to nanotechnology, to peace and conflict, have been seen as suited to transdisciplinary research. Indeed, complexity itself is a key issue and criterion in transdisciplinary research (Nowotny, Scott, \& Gibbons, 2001; Somerville \& Rapport, 2000; see also Bunge, 2003; Taylor, 2001). Mechatronics, which combines mechanics and electronics, exemplifies the innovative approach needed in transdisciplinary research and education (Pop \& Mathies, 
2008). Other key topics in transdisciplinarity include systems thinking, hearkening back to the ideas of Ludwig von Bertalanffy, Kenneth Boulding, and C. West Churchman (Strijbos, 2010), and evaluation (Huutoniemi, 2010).

The definition of transdisciplinarity compared with interdisciplinarity and multidisciplinarity is the subject of a recent paper by David Alvargonzález (2011), which reviews the extensive literature on the subject. Citing Julie Thompson Klein (2010, p. 16), he says that multidisciplinarity involves mere "additive juxtaposition" of different disciplines, resulting in "pseudointerdisciplinarity," while "true interdisciplinarity is interacting, linking, and focusing." Transdisciplinarity, in contrast to both of these, is "transcending, transgressing, and transforming, it is critical, integrative, and restructuring, but, as a consequence of that, it is also broader and more exogenous" (Alvargonzález, 2011, pp. 388-389). But neither author mentions Stephen Jay Kline, who wrote that "multidisciplinary study examines the appropriate relations of the disciplines to each other and to the larger intellectual terrain" (Kline, 1995, p. 2). With the potential for confusion from such hair-splitting and terminological variation, it is understandable that Maria LópezHuertas (2013) groups all the new combinations of disciplines together as "multidimensional knowledge," a way of thinking about knowledge that is in a sense post-disciplinary and postepistemological, and that is gathering momentum. Despite possible confusion among the somewhat overlapping terms, López-Huertas does not consider any of them redundant. The term "transdisciplinarity" makes a useful distinction and is retained here.

While ordinary interdisciplinarity analyzes, synthesizes, and harmonizes links between disciplines into a coordinated and coherent whole, transdisciplinarity seeks to reconstruct knowledge from scratch, recombining the content knowledge of the disciplines into new formations with an aim of recognizing and analyzing all relevant angles on a problem and their dimensions of reality (see Madni, 2007, Pop \& Maties, 2008, Wallerstein, 2004). As noted by Alvargonzález (2011, p. 388 ), the word "transdisciplinarity" connotes in its etymology "going across and through the disciplines, and beyond each individual discipline." Such an approach questions the fundamental assumptions behind the segmentation of knowledge into disciplines.

Transdisciplinarity, in other words, results from a growing recognition among scientists, scholars, and educators of the limitations and distorted priorities of disciplinary thinking. By applying the term "transdisciplinarity" rather than ordinary "interdisciplinarity" to the study of knowledge, I am suggesting that such work transcends disciplinarity by challenging disciplinarity itself and the entire framework of disciplinarian thinking, assembling a new approach from the ground up using the materials of earlier discipline-based studies. The study of knowledge is suited to a transdisciplinary approach not only because of the changing social, economic, and political framework of knowledge production in advanced societies seized on by Gibbons et al. (1994) as signaling a break from the past but because of the unique position of knowledge in relation to all subjects and the need to consider multiple dimensions and angles. Depending on one's definitions, dimensions could include the psychological, the epistemic, the social, and the cultural; the angles would include the idealistic (or analytical), the semantic (or lexical), the bibliographical, the serviceoriented, and the results-oriented.

As a quickly evolving notion, much literature useful in understanding transdisciplinary tendencies maintains the older term "interdisciplinary," or even, as in the case of Kline (1995), "multidisciplinary," and this terminological variation could be a source of confusion in differentiating among them. Kline's work seems highly pertinent to transdisciplinarity, as it describes concepts of hierarchy, complexity, and dimensionality to explain categories of disciplines and the relationships among them. The analytic features described by Kline as fundamental to multidisciplinary thinking have their mathematical basis in category theory (Ehresmann \& Vanbremeersch, 2007; Goguen, 1999). Nevertheless, the chief writers associated with transdisciplinary theory have not 
cited him, and one wonders what role his choice of terminology played in the absence of discussions of his work by transdisciplinarians.

The same can be said of Mario Bunge's book, Emergence and Convergence (2003), which analyzes disciplinarity, cross-disciplinarity, multidisciplinarity, and interdisciplinarity, but not transdisciplinarity. Bunge has diagnosed problems of reductionism, fragmentation, and theoretical shallowness in the standard work of the disciplines and has proposed solutions for crossdisciplinary integration. Bunge writes about emergence and convergence as they relate to complexity, issues one might expect would interest those involved with developing transdisciplinary research. Like Kline's text, Bunge's work has yet to be recognized in the literature on the subject, and one must consider the possibility that his failure to use the specific buzzword "transdisciplinarity" has led to this lack of awareness or inclusion. Mark C. Taylor is yet another recent author whose work deserves to be considered by the transdisciplinarians. Though his book The Moment of Complexity (2001) does not specifically discuss disciplinarity or its variations, like Bunge, he explores emergence, evolution, and other topics pertinent to the study of complexity, information, knowledge, and education.

According to López-Huertas (2013), transdisciplinarity is guided by the demands and conditions of post-Cold War, networked, neo-liberal society, which are very different from those pertinent to the post-World War II period of the authors under discussion. By applying the term to Shera and other authors whose writings on knowledge span the years from 1952 to 1984, I mean to suggest only that the roots of a transdisciplinary approach to knowledge are apparent in their works. In advocating transdisciplinary thinking, I want to encourage students and scholars to imagine new possibilities for thinking about, studying, and researching knowledge. However, I do not claim that it is desirable to do away with any existing disciplines. I agree with Joe Moran's statement (cited by Repko, 2012, p. 35) that "we can never entirely dispense with the disciplines as a means of organizing knowledge ... but we can use them to create new intellectual configurations of knowledge."

\section{Machlup and Polanyi}

In the long run, Shera's reputation remained specific to LIS. But in his time (1903-1982), two other scholars of global renown - Fritz Machlup (1902-1983) and Michael Polanyi (18911976) - independently pursued what I suggest can retrospectively be called the beginnings of a transdisciplinary approach to knowledge. Shera's essay, "An Epistemological Foundation for Library and Information Science," was first presented at a conference in 1965 and was published in 1968 before it was reprinted as a chapter in his 1972 book, The Foundations of Education for Librarianship. In it he cites the works of Machlup and Polanyi with a mixture of praise and criticism, naming The Production and Distribution of Knowledge in the United States (Machlup, 1962) as one of only two books "aimed in the direction of providing a foundation for the kind of discipline indicated here" (Shera, 1972, p. 112).

Before leaving Shera to discuss these authors, one ought to observe that while Shera could be accused of grandiosity in naming his approach social epistemology (even though he refused credit for coining the term) and calling it a new discipline, Polanyi, who subtitled his major book Towards a Post-critical Philosophy (1958), was (perhaps) slightly less pretentious, while Machlup did not give a name to his own approach. Shera criticized Polanyi's psychologized, individualistic notion of knowledge as part of an entire prevailing approach to knowledge he hoped to replace. Polanyi did not respond to this mild criticism and may not have been aware of it. But Shera and Machlup did cross paths. In an odd coincidence, Shera's last paper, submitted only months before his death in 1982, was a contribution to a project organized by Machlup in connection with a book he was planning as part of his series on knowledge, to be called The Disciplines of Information. Machlup himself died not long afterward, before the project could be completed, 
and the book was released as The Study of Information: Interdisciplinary Messages (Machlup \& Mansfield, 1983). Shera's (1983) chapter on the relationship between librarianship and information science is strikingly negative and gloomy in tone, and it does not even mention social epistemology, but rather recommends social interactionism, a sociological theory associated with George Herbert Mead, an early and influential social psychologist (see Wright, 1998).

Fritz Machlup and Michael Polanyi were both scholars trained in old world European traditions, assimilated Jews who escaped the Nazi terror on the continent by emigrating to English-speaking countries in 1933, and both went on to have illustrious careers as eminent professors in their areas of expertise. (Polanyi later converted to Christianity and is highly esteemed by Christian theologians.) Both crossed the boundaries of their home disciplines when they turned their attention in their later years to the study of knowledge, writing numerous substantial works on the subject. As in the Tom Stoppard play Travesties, about a fictional meeting between James Joyce, Vladimir Lenin, and the Dadaist writer Tristan Tzara, one can imagine a meeting between these contemporaries who were luminaries in their own circles, but there is no evidence of any actual contact between them. Machlup, who assiduously surveyed the research literature, cited Polanyi in passing, while Polanyi, who worked on the foundations of knowledge as they relate to individual discovery, had no reason to absorb or respond to Machlup's socioeconomic studies and had passed away by the time Machlup produced his final, more holistic syntheses.

Machlup's professional interest in knowledge as a subject began with questions about patents as a restriction on competition. At first, his focus on knowledge appeared to be but one thread in a distinguished career as an economist that included not only professorships but a consultancy to the US Treasury. His book on the economics of knowledge (Machlup, 1962) went beyond traditional concerns about knowledge as a factor in consumer choices, preferences, and decision making and led to research about an entire sector of the economy devoted to knowledge, and it had major implications for understanding post-World War II civilization. Most importantly, by identifying a shift in the US economy from one focused on the manufacture of physical objects to one in which knowledge production was central, Machlup's work inspired influential books on postindustrial or information age society by the sociologist Daniel Bell (1973), the management guru Peter Drucker (1969), and the futurist author Alvin Toffler (1970).

Machlup began articulating a typology of the kinds and qualities of knowledge that has been recognized (not least of all by Shera, 1972) as one of his greatest insights (cf. Miksa, 1985, Wallace, 2007). He was also among the first to consider the relations between data, information, and knowledge, though some (again, including Shera) chastised him for failing to differentiate clearly between knowledge and information (but see Machlup, 1983). Machlup's research on knowledge carried over to the four-volume Information through the Printed Word (Machlup \& Leeson, 1978-1980), and finally to the magnum opus, Knowledge: Its Creation, Distribution, and Economic Significance (1980-1984), intended to comprehend all categories, aspects, and qualities of knowledge and its analysis. An extremely ambitious undertaking under any circumstances given the complexity, elusiveness, and all-encompassing qualities of knowledge as a subject, it is even more remarkable when one considers that Machlup was 77 when the first volume appeared. The project was originally conceived as eight volumes, but while working on it Machlup determined that the subject required two more volumes than he had first planned. Given his advanced age, it could not have shocked anyone greatly that the project was unfinished at the time of his death, ending up finally with three single-authored volumes plus a co-edited volume encompassing the subject matter of what was to be Volume 4.

This work is most significant in viewing Machlup's contribution to transdisciplinarity, or at least its groundwork. Indeed, Machlup (1980, pp. 21-22) explicitly describes the work as transdisciplinary and acknowledges that it does not satisfy the expectations of specialists who would have preferred his work to be about knowledge as it is specifically seen in economics, the natural sci- 
ences, library (and information) science, or philosophy, as the case may be. The term "transdisciplinary" had only recently been coined and was not yet in common use in 1980, and while Machlup does not elaborate on what he means by using the term along with the more common "interdisciplinary," his work does capture the nascent transdisciplinary spirit, since it moves far beyond the economic questions that first prompted him to focus on questions of knowledge.

Economics was only his entry point into the study of knowledge and provided intellectual grounding. From there, he moved outside economics by using all the tools at the scholar's disposal to explain knowledge not only as an economic phenomenon but also from every other valid angle - cultural, sociological, linguistic, psychological, etc. He brought together the insights from all disciplines as well as from his own thought experiments, an approach borrowed from analytic philosophy. But although knowledge on the whole is thought of as a philosophical problem, Machlup's approach was not properly philosophical, since he did not define knowledge in any analytical way. Instead, he incorporated the inputs of various disciplines, approaching his topic of knowledge as one would a more ordinary topic.

Machlup drew a crucial distinction between the two meanings of knowledge: the process of knowing and that which is known. His lasting contribution to our understanding of knowledge concerns the second meaning. Like the sociologists, Machlup advocated an open concept of knowledge and defined it as whatever people thought was knowledge, without reference to criteria of truth, justification, or evidence. His view of knowledge does not pass muster in disciplines that demand absolute verifiability, logical consistency, measurability, accuracy, and avoidance of error. Philosophers were not satisfied with his study and do not frequently cite it. Yet his work was not properly sociological either, and sociologists did not give it a warmer reception than did the philosophers. Like Shera, he appears to have sought to reach beyond both philosophy and sociology. As a conceptual framework for thinking about knowledge, Machlup's approach, like Shera's, seems most congenial to that of library science in that libraries need exacting standards for bibliographical description and yet cannot not be so rigid about truth claims as to block access to materials. His approach to viewing knowledge as a broad cultural phenomenon and defining characteristic of civilization lives on in works such as Peter Burke's A Social History of Knowledge (2000-2012).

It would be almost as accurate to say that Machlup used no disciplinary foundation as to say that he incorporated all relevant disciplines. His work opened a door to transdisciplinarity, and to the extent that it failed it was because he could not successfully reimagine the disciplines (see Castan Broto, Gislason, \& Ehlers, 2009). Volume 2, The Branches of Learning (Machlup, 1982), describes the organization of disciplines as part of the historical development of universities, along with a description of classification systems in libraries, reference books, and academies of sciences. But beyond bringing these diverse domains of knowledge organization together in a fairly standard historical account, Machlup does not interpret the arrangement of disciplines or subjects and their interplay as an intellectual phenomenon in a way later scholars would. He helped lay the groundwork for the more probing work into the nature of disciplines and other knowledge organizing structures that we find in later writings by such authors as Francis Miksa (1998) and Fred D'Agostino (2012), along with the aforementioned Julie Thompson Klein (1996). Yet the fact that he undertook this exercise suggests he was building toward a later grand synthesis. His most lasting transdisciplinary insight about the five classes of knowledge (practical knowledge; intellectual knowledge; small-talk and pastime knowledge; spiritual knowledge; and unwanted knowledge) had already been introduced in his 1962 book, and his final book series, though respected by many, satisfied neither epistemologists nor social scientists and did not spur others to follow in his path. By contrast, the French scholar Michel Foucault (1926-1984), author of The Archaeology of Knowledge (1969/1972) and Power/Knowledge (1980) among many other books, inspired an international cult-like following among scholars and students in a multitude of disci- 
plines. Foucault's devotees have not only canonized his work but picked up where he left off (see Halperin, 1995).

Michael Polanyi's magnum opus, Personal Knowledge: Towards a Post-critical Philosophy (1958), preceded Machlup's work on knowledge, but it can be usefully seen as a proleptic answer to him, since Polanyi does not look at knowledge as an external phenomenon that must be apprehended by humans, but rather begins with the outlook of the individual inquirer or learner.

Machlup and Polanyi both focused on knowledge production, but while Machlup concentrated on the socioeconomic sense of "production," Polanyi meant something else altogether and introduced an original approach to knowing in terms of the individual's subjective experience of encountering the external world through inquiry, resulting in discoveries. Polanyi saw knowing as an active comprehension of the things known, an action that requires skill. Whereas Machlup, whose works postdate those of Polanyi, took into account his predecessor's approach as describing an aspect of the larger phenomenon of the totality of knowledge, for Polanyi, knowing at the personal level was primary.

While Machlup looked at knowledge as the achievement of civilization, Polanyi focused on the process of knowing from an internal point of view. He looked at understanding, or making sense, as grasping and integrating information to make it knowledge. Consideration of knowing requires a theory of the relationship between the knowing subject and the known object. It includes multiple kinds of knowing, down to sensory perception.

Polanyi trained as a medical doctor before beginning his scientific career as a physical chemist and achieved great distinction before changing his field of interest in his fifties to the social sciences, working at first on labor and employment. But he soon became occupied with big picture questions about scientific knowledge, discovery, and inquiry. His writing about these subjects was prompted by his own experiences as a laboratory scientist. His writings on knowledge cite the major modern philosophers, and his work is recognizable as philosophy. (Personal Knowledge (Polanyi, 1958) originated as Polanyi's Gifford Lectures presented at the University of Aberdeen during the 1951-52 academic year. The Gifford Lectures, in existence since 1888, is one of the world's most prestigious lecture series on religion, science, and philosophy; see www.giffordlectures.org.) But what is most striking is that he skips past the topics that have traditionally dominated philosophical epistemology and writes about the personal engagement with the world that characterizes discovery. Polanyi prioritizes the interests, motives, emotions, and thought paths of the individual knower or inquirer. For him, knowledge is acquired through engaged inquiry, through passion and commitment. The inquirer in his view need not be a professional, skilled, or certified expert but could be anyone - a student or even an interested layman.

Polanyi's experience as a physical chemist taught him that the rigor of scientific procedure was "secondary to the role of the creative imagination. Scientific work cannot be carried out by mere following of rules" (Gelwick, 1977, p. 26). Scientific research requires insight and judgment that surpass method. The difference between conformist research and discovery lies in the personal judgment of the scientist. Polanyi propounded an image of the scientist that was unusual for its time. Rather than portraying the scientist as impersonal, detached, and obsessed with precision and methodology, he idealized an image of the committed engaged scientist on a quest for discovery. For Polanyi, creative thinking in science was akin to art. Polanyi's biographer Richard Gelwick (1977, pp. 47-48) asserted that the approach to knowledge detailed in Personal Knowledge was a not a correction of modern philosophy but a "truly alternative ideal of knowledge," inasmuch as it represents the personal background of the inquirer not as "a hindering factor but the intelligent center of knowledge."

Polanyi's personalistic, almost phenomenological view of the knowledge creation process represented an individualistic approach to knowledge of the kind rejected by Shera, yet it is an essen- 
tial counterweight to the view of knowledge as socially conditioned. More important here is that it extends a view about the nature, value, creation, and development of knowledge in ways that can stimulate research and teaching that challenges conventional thinking about knowledge associated with traditional disciplines.

While Polanyi considered the individual scientist making discoveries through the observation of nature, such an approach can be applied, for example, to inquiries using scholarly resources, to hobbies, or even to the inquiries of a completely untrained person. The nearly dialectical tension between Machlup's study of knowledge as an artifact and Polanyi's work on knowing anticipates Nicolescu's (2012) concern for transdisciplinary research not to reduce the subject to the object or vice versa (cf. López-Huertas, 2013).

Polanyi drew on theories from Gestalt psychology rather than information theory or the sociology of knowledge in analyzing the process whereby inquirers integrated particular details from various sources and kinds of evidence into a single meaningful pattern. This approach to knowing from the inside anticipates Abraham Maslow's (1966) work on positive psychology and Mihaly Csikszentmahalyi's (1990) work on flow. It is even phenomenological in that it refers to bodily awareness and practices, including attention, sensory perception, and involuntary movement of the muscles (Merleau-Ponty, 1945/1962).

Another significant connection in Polanyi's oeuvre is to F. A. (Friedrich) Hayek, a Nobel Prizewinning economist who preceded Machlup in studying the economics of knowledge (Hayek, 1945). A lifelong friendship developed between Polanyi and Hayek over shared scholarly interests along with the fact that both men were distressed about the "threat of scientific Marxism, the spectre of socialism it was casting over Europe, and its implications for the future progress of an autonomous science" (Fischer \& Mandel, 2009, p. 28). In a paper first published in a festschrift for Karl Popper, Hayek (1964) seems to reiterate Polanyi's emphasis on pattern recognition as key to scientific knowledge, though he does not mention him by name. This essay, along with some others published in the 1967 collection, Studies in Philosophy, Politics, and Economics, especially "The Dilemma of Specialization" (originally 1956), suggest Hayek's own gravitation toward incipient transdisciplinary thinking about knowledge. Hayek's work points to a long genealogy to the approach epitomized by Polanyi in Personal Knowledge, since he (Hayek, 1964, p. 322) cites the eighteenth century Scottish philosopher Adam Smith as having made similar observations to Polanyi's about the role of wonder and the pursuit of study for its own sake rather than the "expectation of advantages" being key to scientific inquiry and discovery.

Polanyi has been the subject of several critical studies and he continues to have a cult-like following among loyalist philosophers, some of whom congregate annually for conferences of the Polanyi Society. His ideas also reverberate in the writings of later thinkers such as Juri Lotman (e.g., 2009) who, in terms similar to Polanyi's, argued that scientific creativity is akin to artistic creativity. But on the whole, Polanyi's work was, and remains, generally out of touch with the trends that have dominated the later philosophical and sociological study of knowledge and science. His humanistic, optimistic, even idealistic, view of the scientist stands in stark contrast to the bleak, suspicious, and anti-humanistic outlook on science and even knowledge put forth by many recent scholars, especially those associated with influential postmodernist and deconstructionist traditions (see, e.g., Blum, 1971; Foucault, 1969/1972; Lyotard, 1979/1984; Mourad, 1995; cf. J. H. Gill, 2000). Nor was knowledge for Polanyi a view from nowhere, depersonalized and objective - a view assumed by most mainstream philosophers (Allen, 2004). Rather, knowledge in his view is pursued through inquiry and discovery, resulting from interest and curiosity, which can legitimately be viewed as humane virtues. 


\section{Knowledge Management: A Non-Liberal Arts Alternative}

Polanyi's interest in the interior mental spaces of knowing led him to identify and write at length about something that became the greatest source of his afterlife: the notion of tacit knowledge, referring to knowledge that cannot (easily) be articulated. His most commonly cited example of tacit knowledge was knowledge of how to ride a bicycle (Polanyi, 1966). The term, as reintroduced by Ikojiro Nonaka and Hirotaka Takeuchi (1995), has become the cornerstone of an emergent academic specialty, knowledge management (KM). Because of the popularization of tacit knowledge first by Nonaka and Takeuchi and from them throughout the KM literature as a whole, many people use the term "tacit knowledge" without knowing Polanyi's name, much less that he coined the expression. However, Nonaka and Takeuchi put a spin on the concept of tacit knowledge that Polanyi never suggested (see Wallace, 2007, pp. 30-31) by using the term to describe the knowledge employees in organizations have in their heads that can lead to product improvements, if only it can be transformed into explicit knowledge. The concept of tacit knowledge is used in business modeling to develop ontologies composed of precise terms "exactifying" and summarizing conceptual schemas underlying the tacit assumptions of organization members with different viewpoints (Kilov \& Sack, 2005). KM, therefore, is the toolbox of techniques intended to maximize the value and impact of employees' knowledge by converting tacit knowledge into explicit knowledge, thereby making it actionable.

Although the KM literature is heavy with discussions about the definition of knowledge (especially in relation to information), Thomas Davenport and Laurence Prusak's (1998) widely cited definition of it as justified personal belief that increases an individual's capacity to take effective action is highly suggestive of the way the concept is used in that field. Knowledge, in this view, is an economic product, a resource for the firm or organization, and "human capital," a concept Machlup (1984) expounded on in Volume 3 of his trilogy on knowledge. Knowledge managers devise tools to capture workers' knowledge and make it available to others in the firm so they can use that knowledge to create better products or otherwise respond to market needs. In contrast to philosophy and sociology (among many other disciplines), KM is an applied science, focused not on intellectual enlightenment or the pure advancement of knowledge for its own sake but on results. Specifically, KM develops tools promoting the conversion, transmission, and sharing of knowledge for the benefit of those with a stake in the particular organization, but not for the benefit of the public at large (which would include competitors).

The KM view of knowledge draws on the closely related fields of information science and cognitive science, relying on models of cognition as the processing of information (see Buckland, 1981; De May, 1982; Gleick, 2011; Kochen, 1974; Sowa, 1984). The notion of relating knowledge to information has it that knowledge builds on and synthesizes information, adding value while at the same time refining and filtering it. It takes a great deal of information to get a small amount of knowledge. This view of knowledge as processed information is quite different from previous views of knowledge promoted in traditional humanities and liberal arts educational programs that idealized it as the product of learning and scholarship (see Leary, 1955). The new view stems from the priorities of administration, which is an applied rather than a pure field. In order to be managed, an individual's knowledge must be elicited, codified, and transformed into a sharable format, whether the product is called knowledge or information (McInerney, 2002, p. 1016). Knowledge is hard to specify, much less measure, but if it is described in terms of information it can be quantified, making it useful in administration for accounting and evaluation. Unlike knowledge (a purely mental product), information can be measured as inputs and outputs.

Knowledge management takes a particular view of knowledge that may be contrasted with the view in epistemology and the sociology of knowledge. Epistemology, working solely within the realm of ideas, can be seen as the furthest from concerns about the real world outside academia or the laboratory. The sociology of knowledge also deals with ideas and the relationships between 
them, but is oriented toward the real world in its concern with behaviors surrounding "knowledge" defined as a socially pervasive sense of certainty, whether or not it is epistemically justified. In contrast to both, KM is not concerned with the interplay of ideas as theories in the abstract but as they can be applied for real world solutions and results, especially in an organizational or business context.

Knowledge in KM is viewed as an asset that can and ought to be managed, a means to an end rather than a good in its own right. It is not an absolute or ultimate objective but rather a quality whose value and purpose must be justified. Not only does the meaning of knowledge need to be put into a framework to make it accessible for use but its value to the organization must be assessed and managers must find the best way to deploy it for the betterment of the organization and its stakeholders. A managerial approach to knowledge or any other asset in an organizational context would seek to control it effectively, maximize its value, and extract that value from it.

Another way of looking at the service orientation of KM is to consider the closely related informing science framework of Eli B. Cohen $(2009$, p. 6), which emphasizes "provid[ing] one's clientele with information in a form, format, and schedule that maximizes its effectiveness." Cohen's notion of clientele encompasses not only business clients, but persons in many kinds of situations ranging from library patrons to patients to owners of machinery who need information. Cohen thus rejects the equation of a disciplinary concern with service to a client's needs as a business or even management orientation, and includes both KM and LIS (library and information science) under the rubric of informing science. In particular, knowledge organization (KO), the branch of library and information science that studies and develops taxonomies, classification systems, and related forms of record organization and knowledge representation, is an informing science because it studies knowledge not in the abstract but for applied, pragmatic purposes (see Smiraglia, 2002). An example of the pragmatic orientation of library science is the cataloging rule stating that works should be entered under the author's name as it appears in the text, even if it is a pseudonym. The purist approach of entering the work under the author's real name might be justifiable as more academically correct but it would likely hamper readers' efforts in finding the works.

Shera himself foreshadowed KM in 1961when he wrote that librarianship was fundamentally "the management of knowledge." With a theoretical grounding in social epistemology, "the very foundations of the librarian's theoretical knowledge," librarianship could be a true profession, the aim of which is "to maximize the social utility of graphic records, whether the patron is an unlettered child absorbed in his first picture book or an advanced scholar engaged in some esoteric inquiry" (Shera, 1961, p. 770). Shera would likely have agreed with the suggestion that librarianship was an informing science: as befits a true profession (as opposed to a respectable trade), it needed a theoretical basis, and the theory most important to librarianship was the theory of knowledge. KO, which grew in part out of Shera's theories of bibliography, likewise is involved in developing systems to serve client needs, but it also has a purist side focusing on the structuring of knowledge through hierarchy, domains, resemblance, the semantics of taxonomy, and so on. Ingetraut Dahlberg (2006), one of the founders of KO, maintains that it qualifies as a separate, objective science studying the structure and form of all sciences.

Looked at as a movement or approach to knowledge, KM poses an interesting challenge to the purer scholarly disciplines. References in the KM literature to Machlup and especially Polanyi (as well as many others who have written about knowledge) indicate that KM scholars have worked through the relevant literature on knowledge originating outside the organizational and managerial sciences themselves in developing their own approach (Alavi \& Leidner, 2001, Martin, 2008). But they have repurposed their discussions and conclusions from purist educational frameworks into a managerial framework and have added concerns for efficiency and a client orientation that were absent in the original writings. While a purely academic subject like phi- 
losophy, and even applied disciplines like education and library science, might look at knowledge as an unqualified good whose value cannot be questioned, KM asks what exactly is the benefit gained from knowledge, and under what conditions. One wants the benefits, not necessarily the knowledge.

In treating knowledge as a resource that needs to be elicited from knowledge workers for the benefit of the firm rather than a good in its own right, the KM viewpoint seems contrary to an educational or liberal arts viewpoint. In liberal arts, educational, or scholarly approaches, curiosity and interest motivate the quest for knowledge, and understanding and the development of knowledge are the goals. Such an emphasis seems to be underscored in Polanyi's writings. The $\mathrm{KM}$ viewpoint is rather different, viewing knowledge as control over a system. The advent of a view of knowledge that does not prioritize its intellectual value as an end in itself is not necessarily cause for worry to more purist educators or scholars, but one wonders if such an approach loses sight of intellectual virtues and would like to find a common ground connecting KM with a liberal arts agenda on fundamental issues, including the meaning and significance of knowledge.

\section{The New Environment of Knowledge and Information}

In retrospect, the period in which Shera, Machlup, and Polanyi worked represented the pinnacle of success of academic science and scholarship. Academic man was at the height of his powers, especially in the USA (Jencks \& Riesman, 1968). (The use of the masculine pronoun for all academics exposes the prevailing consciousness of the times in taking for granted the significance and even existence of distinct female academic voices. Such a usage would no longer be accepted on stylistic grounds, nor would it accurately reflect more recent institutional realities, as Finkelstein, Seal, and Schuster's 1998 work shows.) Since that time we have witnessed what Bill Readings (1995) has called "the university in ruins," when faith in the ability of the academy to solve problems has declined, as has respect for scholars, scientists, and universities. Equally important, the prospects for the academic professions have been thrown in doubt as universities have replaced traditional faculty-focused operating models with managerial ones governed by bottom-line concerns (Dijkstra, 1994, Donoghue, 2008, Kirp, 2003, Waters, 2004). Knowledge management represents a "real world" approach to the study of knowledge disconnected from the purist aims of the academy, as we have seen. Gibbons et al. (1994), followed by Nowotny, Scott, and Gibbons (2001), described a new system for the production of knowledge, called mode two knowledge, in which universities are not so central or may be circumvented altogether as laboratories are created by industries or are government-supported but based off campus, bringing in experts from multiple disciplines for specific projects. It was in this recent context that contemporary views about transdisciplinarity emerged.

The place of knowledge in the world at present cannot be described without taking into account the revolutionary changes in communication and information use caused by the development and popularization of information technology. The post-World War II environment, during the dawn of the computer age, in which Shera and other LIS pioneers experimented with information retrieval systems (see Wright, 1998), is barely comprehensible to people today who take for granted ubiquitous, round-the-clock access, availability, and findability.

Much has been written about changes in the ways people locate, browse, and read information as a result of new technology (e.g., Cull, 2011, Rice, McCreadie, \& Chang, 2001, Shoham, 2000, Ulin, 2010). But knowledge is something different from information behavior, and it requires different conceptual models and research strategies. Despite the complex interconnections between knowledge and information that make it possible in many cases to use the words interchangeably (Buckland, 1981), knowledge, unlike information, is a mental phenomenon and cannot be reduced to information. Knowledge and information have different conceptual links. Knowledge is related to concepts, ideas, facts, and certainty, while information is related to com- 
munication, messages, accuracy, and vehicles of message transmission. (Notice that the meanings of "certainty" and "accuracy" are similar but not identical, since the former is absolute while the latter is probabilistic.)

Indeed, one could argue that the development of information theory in connection with the rise of computer technology (Gleick, 2011) created the conditions that led to the "tendency to conflate knowledge and information" (Kenway, Bullen, \& Fahey, 2006, p. 16). For example, KM theorist Keith Devlin (2001, p. 15) defined knowledge in terms of information with the formula, "Knowledge $=$ Internalized information + Ability to utilize the information." Information scientists similarly define knowledge in terms of information: Marcia Bates (2005) defined knowledge as information given meaning and integrated with other contents of understanding, while Jason Farradane (1980) defined information as the physical surrogate of knowledge. Joseph Nitecki (1985) sees information and knowledge as stages in a single process.

The notion that knowledge is related to information is in keeping with the changes wrought by the implementation of computer technology. As we have already seen, such an identification is linked to a notion of knowledge as related to control, which was not a factor in traditional concepts of knowledge but which is useful in understanding information as a measurable, quantitative, possibly material entity. Knowledge being viewed as information, which can be measured, has led to professors increasingly being evaluated on the metrics of their productivity. Faculty members face contradictory pressures to expand the horizons of specialist knowledge while teaching the basics and generalities. Nowhere are such contradictions felt more keenly than in the humanities (Miller, 2012). These fields face a crisis of faith in their continuing relevance. One should also mention backlash from the humanists, with some writers, notably Theodore Roszak (1994), vehemently rejecting the reduction of knowledge to information, or, to put it another way, the elevation of information to the status of knowledge. Roszak's work is a critique of experts who herald the information age and reliance on computers as something that will better society. In his words, information does not create ideas, and the mind thinks with ideas, not with information (Roszak, 1994, p. 88).

As an object of study, knowledge is harder to keep in focus than is information. Information science (or studies) has gained momentum as a field of research and practice (Saracevic, 1999), while knowledge studies does not yet exist in such a sense, despite the occasional use of the term by Klein $(1996$, p. 2; 2000a). The closest examples we have of disciplinary identification with the study of knowledge are KM and KO, both of which are not only applied fields but are oriented to a significant extent around satisfying the needs of clients (cf. Cohen, 1999, 2009).

Taking the informing process as a starting point for analysis, the computer scientist Eli Cohen and his colleagues at the Informing Science Institute (Murphy, 2011) explicitly seek to develop a transdisciplinary synthesis among specialists from various disciplines bringing together research and applications focused on informing. Such a synthesis requires a new kind of theoretical framework that must take into account practices, mental representations, and policy issues along with technological and managerial concerns. As such, this network of scholars reflects on previous work in information science, cognitive science, and KM, and seeks to broaden the context even further in taking the next step in advancing theory. Zbigniew Gackowski (2010) has recently formalized multiple paradigms of informing to serve as the basis of a separate discipline, defining informing as "the science and art of practical endeavors to increase its effectiveness, ethics, and/or efficiency in extending knowledge and control over reality" (p. 171). Recent articles in the journal Informing Science have taken up the challenge of filling in these new paradigms of informing as paramount to discussions about the nature of knowledge by covering the diffusion of knowledge in society (Losee, 2014), quality assurance as a criterion in the definition of knowledge (Gackowski, 2012), and the value of theoretical and conceptual schemes based on criteria of accuracy in describing reality versus notions of usefulness or practicality in developing solutions 
(T. G. Gill, 2011). Clearly, the contributors to the informing science literature recognize the need somehow to fuse and combine applied and purist objectives in the study of knowledge.

A few other writers outside this movement have also stepped outside disciplinary thinking and have implicitly or explicitly embraced transdisciplinarity in analyzing knowledge. As such, they can be seen as following in paths charted by the incipient transdisciplinarians discussed earlier. The remainder of this essay is devoted to examining three recent full-length works specifically on knowledge (only the first two focus on the networked age). They provide an intriguing sense of the potential for creative thinking and future research on the subject of knowledge.

\section{Recent Transdisciplinary Studies of Knowledge}

The current climate is one in which the ground has shifted in several ways from the baseline of the post-World War II period seen here as the starting point for moving beyond traditional disciplinary silos in studying knowledge. The end of the Cold War occurred around the same time as the development of the public Internet and was followed soon thereafter by the unveiling of the World Wide Web. This was about the same time that the landmark text by Gibbons et al. (1994) appeared, popularizing the notion of transdisciplinarity. Following the reception of this book and its sequel (Nowotny et al., 2001), the period has been a favorable one for transdisciplinary cooperation, at least at the planning level, though projects that seem viable on paper may be prone to fall into the gap because of difficulties of funding and administration (Pfirman \& Martin, 2010). Theories of transdisciplinarity call into question traditional assumptions about the procedures of science and the production of knowledge. The advent of transdisciplinary research and education seems to demand that we wipe the slate clean and develop a fresh approach to the meaning of knowledge, beyond thinking of it mainly in terms of information.

On a fundamental level, our manner of knowing (not just being informed) and our sense of what knowledge is, has arguably shifted away from the familiar milieu of authoritative knowledge and expertise, science, education, reliable sources, etc. Among the most interesting voices to weigh in on this phenomenon has been that of David Weinberger, a technology writer whose latest book, Too Big to Know (2011), suggests that conventional ways of thinking about knowledge, as a unified structure, for example, can no longer be justified. Much of the obsolescence of customary foundations of knowledge can be attributed to the transformations wrought by information technology not only on reading, writing, and other communication, but also on banking, shopping, office work, personal relationships, voluntary associations, political action, police and military surveillance, and almost anything else one can think of. The reason is not the technology (hardware and software) itself, but the new modes of communication enabled by global connectivity that have become ubiquitous almost overnight, leading to new social structures, new vocabularies and systems of etiquette, contact between persons who could never have crossed paths before, and so on. Smart phones, global positioning systems, social media, file sharing, Google Books, Web 2.0, online casinos, and massive open online courses are but a few innovations, each mind boggling in its own right, that seemed unfathomable when the end of the Cold War heralded the dawn of the globalized age. With knowledge being networked in ever more new ways, Weinberger (2011, p. xiii), asserts that knowledge "is becoming inextricable from-literally unthinkable without - the network that enables it." Traditional notions about knowledge (for example, as a body of vetted works), have their origin in the technology of paper-based communication. Networked knowledge has no shape, structure, or foundation, and notions of factuality and evidence have shifted to the extent that, to quote the provocative subtitle of his book, "the smartest person in the room is the room." A case against this somewhat alarmist claim can be found in Hayek's (1967, pp. 96-105) observation that not all institutions are planned or designed. As a case in point, he demonstrates that law is "the result of human action but not of human design," and the same argument may be made about knowledge. Nevertheless, Weinberger touches on a 
real cultural shift in attitudes about knowledge that has already affected everyday practices and mass media, and that may in the long run also affect education, formal science, and research.

The manner in which Weinberger analyzes the evolving context of humans' relationship to knowledge and information resources is somewhat sociological, but ultimately it seems to lie outside the disciplinary communication system altogether. Weinberger's Ph.D. is in philosophy (his dissertation is on Heidegger) but his position at Harvard University's Center for Internet \& Society situates him at the margins of academia as a public intellectual. Not having to answer to disciplinary or departmental requirements perhaps frees him to concentrate on writing for trade publishers, which in turn enables him to eschew disciplinarity, since trade books do not need to fit into any list relating to curricular programs. Too Big to Know follows similar books by Clay Shirky (2010) and Cass Sunstein (2008) that deal with issues of cognitive authority and decision making in the new frontier of global connectivity. What differentiates Weinberger's book from theirs is its ultimate purpose of addressing questions about the nature and significance of knowledge itself.

Even though Weinberger's subject matter, knowledge, is highly scholarly, he cites very little scholarly monographic or journal literature. It is the academic literature, of course, that is most heavily shaped by disciplinarity. Weinberger's focus on real world phenomena outside the walls of the ivory tower connects his work to KM, but he is skeptical of managerial notions of knowledge as processed information or something related to control, utility, or getting things done. Moreover, he does not view knowledge as a resource, nor does his book describe techniques of maximizing value from human capital, explicating tacit knowledge, or serving the needs or wishes of clients. In its own way it is a purist, unapplied attempt to put into layman's terms a pervasive change in the fundamental meaning of knowledge in a networked, post-paper civilization.

David Hakken (2003) uses the term "cyberspace" to refer to this new stage of civilization. This now-familiar word was coined by William Gibson in the 1984 science fiction novel Neuromancer as the name of a nightmarish realm entered by a character in the book when he plugged into a networked computer (Hakken, 2008). Writing in 1999, Hakken foresaw that cyberspace, by which he meant "the type of culture being created via Advanced Information technology (AIT), the congeries of artifacts, practices, and relationships coming together around computing" was about to become "the dominant mode of human existence" (p. 1). His book $C y$ borgs@Cyberspace? (1999) examined the problems of and prospects for ethnographic research on cyberspace. His subsequent book, The Knowledge Landscapes of Cyberspace (2003), focused specifically on questions about the nature of knowledge in this new environment, particularly the question of whether the character or social functions of knowledge have changed fundamentally - a question similar to that which motivated Weinberger's text, but asked right before the introduction of hardware and software that had already changed the knowledge landscape when Weinberger wrote his book just a few years later. Hakken, who holds a Ph.D. in anthropology and who identifies himself as an anthropologist, moved from an interdisciplinary stance combining anthropology and computer science (or rather informatics - see below) toward a transdisciplinary approach to knowledge.

As an anthropologist, his work takes into account anthropological theories of culture and the application of ethnographic methodologies to cyberspace. Clearly, the intellectual space Hakken claims corresponds to the anthropology of technology (see Pfaffenberger, 1992). But he also covers epistemology, sociological theory and the sociology of science, and knowledge management. Though he cites only one social epistemologist (Kornblith, 1994), Hakken's work in itself also approximates social epistemology. Additionally, his work engages with informatics (the practices surrounding the use of computers). Hakken prefers this term for the discipline commonly known as "computer science" since he does not consider computing (or AIT as he calls it, 
short for Automated Information Technologies) to be a naturally occurring domain requiring its own "science." "Computer science" seems to be over-selling the scientific-ness of computer use, in the same manner as do terms like "automotive science" or even "information science," for that matter. The informatics approach to knowledge is an information-processing one that aims to model human cognition by analogy to artificial intelligence (AI). Hakken rejects AI as a paradigm and wants to study ethnographically how humans engage with computers at work, in education, and in recreation. Knowledge, he asserts, cannot be understood stripped of its social dimension.

Similar to Polanyi, Hakken approaches knowledge as a process he calls knowledging rather than viewing knowledge as intellectual content, but like Machlup and Shera (and unlike Polanyi) he advocates "replacing individualistic conceptions of knowledge with more social ones" (Hakken, 2003 , p. 13). Years before Weinberger, he foresaw that computer networking would change the nature of how humans know, the general significance of knowing, and the social organization of knowledge. Dissatisfied with KM, he proposes ethnographic methods and theories derived from anthropology to flesh out the social textures neglected in managerially driven studies and applies his ethnographic approach to non-governmental organizations and universities. His book covers the theoretical and methodological problems of studying networked knowledge in organizations and in education. As a social science approach to networked knowledge, it can be seen as anticipating and laying the groundwork for Lee Rainie and Barry Wellman's (2012) study of social networks sponsored by the Pew Research Center's Internet and American Life Project.

A different, recent transdisciplinary approach has been launched by the Danish scholar Søren Brier, who, in an array of publications culminating in a major treatise published in 2008, proposes to reintegrate all disciplines related to information, cognition, and communication. Unlike the authors discussed above, Brier does not specifically address issues relating to advanced information technology. Brier's approach takes into account physical and chemical reality, biological evolution, socially, culturally and linguistically constructed reality, and the phenomenology of individually experienced reality. Cybersemiotics, as he calls his approach, is daringly and brashly transdisciplinary through and through. The challenge he lays down is evident, for example, in the subtitle of his nearly 500 page book: Why information is not enough! In other words, information is only the starting point in looking at the complexities of human knowledge. His work is unique and hard to categorize, but it has its roots in a remarkably broad spectrum of scholarship. If one had to assign his approach (and particularly his book) to just one category, one might call it philosophy, so global and all-encompassing is its scope.

From the term he chose to name his approach, one can tell that his chief inspirations are the cybernetics of Norbert Wiener and the semiotics of Charles Peirce and Thomas Sebeok. Other major sources influencing his work are the animal behaviorists Jakob von Uexküll and Konrad Lorenz, the phenomenologist Edmund Husserl, and the sociologist Niklas Luhmann. He also copiously cites writings by the polymath Gregory Bateson, whose research combined cybernetics, psychiatry, and anthropology, and the co-authored works of the neuroscientists Humberto Maturana and Francisco Varela on autopoiesis (self-organizing systems). Beyond the fact that most of the authors just mentioned were themselves disciplinary border crossers engaging in their own forms of transdisciplinarity, it should be noted that Brier explicitly labels his work as transdisciplinary, citing key authors on transdisciplinary research such as Edgar Morin, Michael Gibbons, Helga Nowotny, and Erich Jantsch, and he discusses and probes the notion of transdisciplinarity, incorporating the concept into his mission. Though Brier does not cite him, he also seems to follow in the tradition of the Russian literary scholar Juri Lotman, who proposed the notion of a semiosphere including both biological and cultural reality, recognizing a common ground between the humanities and the natural sciences (Gherlone, 2013a, 2013b; Lotman, 1984/2005). He cites the literature on information theory (e.g., Shannon \& Weaver, 1949) and information proc- 
essing in cognitive and library and information science, touching on writings by both Machlup and Polanyi. In light of Brier's professorship in a business school, it is noteworthy that he does not refer to the literature on $\mathrm{KM}$ or to management issues.

Obviously, cybersemiotics is an extremely subtle and complex concept taking into account numerous theories not covered in this essay. Clearly, Brier's work is important in constructing new approaches to knowledge in connection with research and education. As difficult as it is to sum up his position in a few words, the following quote may illuminate his own view about the nature of his contribution. In a chapter called "The self-organization of knowledge: Paradigms of knowledge and their role in deciding what counts as legitimate knowledge," Brier writes:

I promote an epistemology that treats science as only one aspect of our knowledge, and human knowledge as extending beyond language into the hypercomplex .... This nonreductionist framework promises to open up a non-Cartesian, transdisciplinary understanding of how knowledge is generated and communicated in society, and without losing what has been gained through the rigor and methods of either the sciences or the logic of philosophical analysis. (2008, p. 103)

\section{Conclusion}

This essay grew out of a sense that knowledge, which is intangible and ineffable, has a paradoxical role as the heart of all intellectual life and thus the defining measure of progress and civilization and the underlying raison d'etre of universities and libraries. Concepts of knowledge are essential in all aspects of inquiry, writing, and practice. Thus, the various compartments of study, research, and teaching cannot contain it. Knowledge is so basic to academic and educational thought and discourse as to be taken for granted as furniture, making it difficult to locate the literature on knowledge. Of course, philosophers, who are the original scholars, have been pondering the nature of knowledge since time immemorial. Beyond that, however, we find that the concept of knowledge is highly flexible and susceptible to being subordinated to disciplinary priorities. While philosophy examines knowledge along with other ultimate fundamentals such as beauty, truth, value, and virtue, in purely analytical terms, the other disciplines also work with and often theorize about knowledge as it applies to their own domains.

The result is a scattering of scholarly and academic discourses on knowledge that lack a common ground. More generally, as the study of knowledge is taken over by scholars in the management area, it loses touch with the humane and liberal arts tradition of scholarship essential to higher education and libraries. Meanwhile, humanists studying classical or postmodern philosophies and social scientists conducting ethnographic studies of knowledge practices are prone to be unaware of the potential insights of the KM theorists on knowledge work and the value of knowledge. With knowledge understood in such fundamentally different ways in the different disciplinary approaches, one might sympathize with the tendency of scholars to retreat into their customary ways of thinking about and working with knowledge. At the same time, the recent overwhelming changes in the way information is handled and processed as well as its changed meaning can lead one to reject the new knowledge practices as dumbed-down or an instance of mind control (cf. Roszak's, 1994, characterization of his own diatribe against information technology as "neo-Luddite"). A possible bridge between at least some of the alternative epistemologies can be found in the philosophy of information, as in the writings of Fred Dretske (1981/1999) and Luciano Floridi (2011). But as this essay has argued, equating the study of knowledge with that of information is at some level misguided.

What is missing, and what this article advocates, is a re-visioning of the study of knowledge that would bring different viewpoints about knowledge into dialogue. This task would be made possible by a transdisciplinary focus on the study of knowledge. Transdisciplinarity is a current 
trend gathering force in education with applications in science, technology, and planning, as well as larger global problems. Because of the unique position of knowledge in the scheme of subject areas, such an approach seems highly appropriate and timely for the study of knowledge. A move by scholars to discard historical separations between disciplinary domains and re-envision the meaning of knowledge for humans now and in the future, could, ideally, help revitalize the humanities and social sciences. It would, for example, enable scholars to take up Andrew Abbott's (2008, p. 525) challenge to create "a body of theoretical or even empirical speculation about the nature of library-based scholarship as a general social form: how it is that each individual library project comes together into a whole and how it is that many such projects come together into something we call knowledge."

As this historical-critical study has shown, such an effort has its roots in the works of Machlup and Polanyi, which would be prominent in a suggested core reading list on knowledge studies. It is also borne out in the efforts of Shera to merge philosophical epistemology and the sociology of knowledge under a library science umbrella. More recently, the literature on disciplinarity and its variations (including transdisciplinarity) puts into focus the problems with segmenting and recombining subject domains. Moving up to the present time, the writings of Weinberger, Hakken, and Brier exemplify current works that eschew disciplinary boundaries in figuring out problems about knowledge. Their writings illuminate new challenges to students and scholars as they try to make sense of the ever-changing knowledge landscape.

\section{Acknowledgments}

Earlier versions of parts of this article were presented at the 13th International Conference on Knowledge, Culture and Change in Organizations in Vancouver, the Faculty Forum at Kingsborough Community College in Brooklyn, New York, and the 13th International Conference of the International Society for Knowledge Organization in Krakow. The author thanks Wendy Chu, James W. Marcum, Janet Tanke, Dominic Wetzel, the editor of Informing Science, and an anonymous reviewer for their helpful comments on an earlier draft.

\section{References}

Abbott, A. (2008). The traditional future: A computational theory of library research. College \& Research Libraries, 69(6), 524-545.

Alavi, M., \& Leidner, D. E. (2001). Review: Knowledge management and knowledge management systems: Conceptual foundations and research issues. MIS Quarterly, 25(1), 107-135.

Alcoff, L. M. (Ed.). (1998). Epistemology: The big questions. Malden, MA: Blackwell.

Allen, B. (2004). Knowledge and civilization. Boulder, CO: Westview.

Alvargonzález, D. (2011). Multidisciplinarity, interdisciplinarity, transdisciplinarity, and the sciences. International Studies in the Philosophy of Science 25(4), 387-403.

Anderson, C. H., \& Murray, J. D. (Eds.). (1971). The professors: Work and life styles among academics. Cambridge, MA: Schenkman Publishing Company.

Bates, M. J. (2005). Information and knowledge: An evolutionary framework for information science. Information Research, 10(4), paper 239. Retrieved from http://informationr.net/ir/10-4/paper239

Becher, T. (1989). Academic tribes and territories: Intellectual enquiry and the culture of disciplines. Milton Keynes, Bucks, England: Society for Research into Higher Education and Open University Press.

Bell, D. (1973). The coming of post-industrial society: A venture in social forecasting. New York: The Free Press.

Benson, O., \& Stangroom, J. (2006). Why truth matters. London: Continuum. 
Berger, P. L., \& Luckmann, T. (1967). The social construction of reality: A treatise in the sociology of knowledge. Garden City, NY: Anchor Books.

Bernstein, J. H. (2009a). Nonknowledge: The bibliographical organization of ignorance, stupidity, error, and unreason: Part one. Knowledge Organization 36(1), 17-29.

Bernstein, J. H. (2009b). Nonknowledge: The bibliographical organization of ignorance, stupidity, error, and unreason: Part two. Knowledge Organization 36(4), 249-260.

Blackler, F. (1995). Knowledge, knowledge work, and organizations: An overview and interpretation. Organization Studies 16(6), 1021-1046.

Blum, A. F. (1971). The corpus of knowledge as a normative order: Intellectual critiques of the social order of knowledge and commonsense features of bodies of knowledge. In M. F. D. Young (Ed.), Knowledge and control: New directions for the sociology of education (pp. 117-132). London: CollierMacmillan.

Brier, S. (2008). Cybersemiotics: Why information is not enough! Toronto: University of Toronto Press.

Broudy, H. S. (1977). Types of knowledge and purposes of education. In R. C. Anderson, R. J. Spiro, \& W. E. Montague (Eds.), Schooling and the acquisition of knowledge (pp. 1-17). Hillsdale, NJ: Lawrence Erlbaum Associates.

Buckland, M. (1981). Information and information systems. New York: Greenwood.

Budd, J. M. (2002). Jesse Shera, sociologist of knowledge? Library Quarterly, 72(4), 423-440.

Budd, J. M. (2004). Academic libraries and knowledge: A social epistemology framework. Journal of Academic Librarianship, 30(5), 361-367.

Bunge, M. (2003). Emergence and convergence: Qualitative novelty and the unity of knowledge. Toronto: University of Toronto Press.

Burke, P. (2000-2012). A social history of knowledge (Vols. 1-2). Cambridge, England: Polity Press.

Campbell, D. T. (1969). Ethnocentrism of disciplines and the fish-scale model of omniscience. In M. Sherif \& C. Sherif (Eds.), Interdisciplinary relationships in the social sciences (pp. 328-347). Chicago: Aldine.

Carlin, A. P. (2009). Segmented professions: Further considerations of theory and practice in LIS and librarianship. Library Philosophy and Practice (e-journal), paper 294. Retrieved from http://digitalcommons.unl.edu/cgi/viewcontent.cgi?article=1299\&context=libphilprac

Castan Broto, V., Gislason, M., \& Ehlers, M.-H. (2009). Practising interdisciplinarity in the interplay between disciplines: Experiences of established researchers. Environmental Science and Policy, 12(7), 922-933.

Child, A. (1941). The theoretical possibility of the sociology of knowledge. Ethics, 51(4), 392-418.

Child, A. (1947). The problem of truth in the sociology of knowledge. Ethics, 58(1), 18-34.

Cohen, E. B. (1999). Reconceptualizing information systems as a field of the transdiscipline: From ugly duckling to swan. Journal of Computing and Information Technology, 7(3), 213-219.

Cohen, E. B. (2009). A philosophy of informing science. Informing Science: The International Journal of an Emerging Transdiscipline, 12, 1-15. Retrieved from http://inform.nu/Articles/Vol12/ISJv12p001015Cohen399.pdf

Csikszentmihalyi, M. (1990). Flow: The psychology of optimal experience. New York: Harper Perennial.

Cull, B. (2011). Reading revolutions: Online digital text and implications for reading in academe. First Monday, 16(6). Retrieved from http://firstmonday.org/ojs/index.php/fm/article/view/3340/2985

Curtis, J. E., \& Petras, J. M. (Eds.). (1970). The sociology of knowledge: A reader. New York: Praeger.

D’Agostino, F. (2012). Disciplinarity and the growth of knowledge. Social Epistemology, 26(3/4), 331-350. 
Dabars, W. B. (2008). Disciplinarity and interdisciplinarity: Rhetoric and context in the American research university. Ph.D. dissertation, University of California, Los Angeles. Proquest Dissertations \& Theses Full Text. UMI Dissertations no. 3347020.

Dahlberg, I. (2006). Knowledge organization: A new science? Knowledge Organization, 33(1), 11-19.

Davenport, T. H., \& Prusak, L. (1998). Working knowledge: How organizations manage what they know. Boston: Harvard Business School Press.

De May, M. (1982). The cognitive paradigm: An integrated study of scientific development. Chicago: University of Chicago Press.

Devlin, K. (2001). Infosense: Turning information into knowledge. New York: W. H. Freeman.

Dijkstra, E. W. (1994, Feb.). The strength of the academic enterprise. Unpublished talk retrieved from http://www.cs.utexas.edu/users/EWD/transcriptions/EWD11xx/EWD1175.html

Donald, J. G. (1986). Knowledge and the university curriculum. Higher Education, 15(3/4), 267-282.

Donald, J. G. (1995). Disciplinary differences in knowledge validation. In N. Hativa \& M. Marincovich (Eds.), Disciplinary difference in teaching and learning: Implications for practice (New directions for teaching and learning, no. 64) (pp. 7-17). San Francisco: Jossey-Bass.

Donoghue, F. (2008). The last professors: The corporate university and the fate of the humanities. New York: Fordham University Press.

Dretske, F. (1999). Knowledge and the flow of information. Stanford, CA: CSLI Publications. (Original work published 1981).

Drucker, P. F. (1969). The age of discontinuity: Guidelines to our changing society. New York: Harper \& Row.

Duderstadt, J. J. (2000). A university for the 21st century. Ann Arbor: University of Michigan Press.

Durkheim, E. (1938). The rules of sociological method ( $8^{\text {th }}$ ed.) (S. A. Solovay \& J. H. Mueller, Trans.; G. E. G. Catlin, Ed.). New York: The Free Press. (Original work published 1895).

Egan, M. E., \& Shera, J. H. (1952). Foundations of a theory of bibliography. Library Quarterly, 22(2), 12537.

Ehresmann. A. C., \& Vanbremeersch, J.-P. (2007). Memory evolutive systems: Hierarchy, emergence, cognition. Amsterdam: Elsevier.

Farradane, J. (1980). Knowledge, information, and information science. Journal of Information Science 2(2), 75-80.

Finkelstein, M. J., Seal, R. K., \& Schuster, J. H. (1998). The new academic generation: A profession in transformation. Baltimore: Johns Hopkins University Press.

Finkenthal, M. (2001). Interdisciplinarity: Toward the definition of a metadiscipline? New York: Peter Lang.

Fischer, F., \& Mandell, A. (2009). Michael Polanyi's republic of science: The tacit dimension. Science as Culture, 18(1), 23-46.

Floridi, L. (2011). The philosophy of information. Oxford: Oxford University Press.

Foucault, M. (1972). The archaeology of knowledge (A. M. S. Smith, Trans.) New York: Harper Colophon Books. (Original work published 1969).

Foucault, M. (1980). Power/knowledge: Selected interviews and other writings, 1974-1977 (C. Gordon, Ed. and Trans.). New York: Pantheon Books.

Fuller, S. (2002). Knowledge management foundations. Boston: Butterworth Heinemann.

Fuss, D. (1989). Essentially speaking: Feminism, nature, and difference. New York: Routledge. 
Gackowski, Z. J. (2010). Informing as a discipline: An initial proposal. Informing Science: The International Journal of an Emerging Transdiscipline, 13, 165-175. Retrieved from http://www.inform.nu/Articles/Vol13/ISJv13p165-175Gackowski565.pdf

Gackowski, Z. J. (2012). The helix of human cognition: Knowledge management according to DIKW, E2E, and the proposed view. Informing Science: The International Journal of an Emerging Transdiscipline, 15, 93-119. Retrieved from http://www.inform.nu/Articles/Vol15/ISJv15p093119Gackowski614.pdf

Gelwick, R. (1977). The way of discovery: An introduction to the thought of Michael Polanyi. New York: Oxford University Press.

Gettier, E. L. (1963). Is justified true belief knowledge? Analysis, 23(6), 121-123.

Gherlone, L. (2013a). Lotman's epistemology: Analogy, culture, world. Sign Systems Studies, 41(2/3), $312-$ 338.

Gherlone, L. (2013b). Semiotics and interdisciplinarity: Lotman's legacy. Sign Systems Studies, 41(4), 381404.

Gibbons, M., Limoges, C., Nowotny, H., Schwartzman, S., Scott, P., \& Trow, M. (1994). The new production of knowledge: The dynamics of science and research in contemporary societies. London: Sage.

Gill, J. H. (2000). The tacit mode: Michael Polanyi's postmodern philosophy. Albany: State University of New York Press.

Gill, T. G. (2011). When what is useful is not necessarily true: The underappreciated conceptual scheme. Informing Science: The International Journal of an Emerging Transdiscipline, 14, 1-32. Retrieved from http://www.inform.nu/Articles/Vol14/ISJv14p001-032Gill589.pdf

Gilovich, T. (1991). How we know what isn't so: The fallibility of human reason in everyday life. New York: The Free Press.

Gleick, J. (2011). The information: A history, a theory, a flood. New York: Pantheon Books.

Goguen, J. (1999). An introduction to algebraic semiotics, with application to user interface design. In C. L. Nehaniv (Ed.), Computation for metaphors, analogy, and agents (Lecture Notes in Artificial Intelligence, 1562), (pp. 242-291). Berlin: Springer.

Gross, P. R., \& Levitt, N. (1994). Higher superstition: The academic left and its quarrels with science. Baltimore: Johns Hopkins University Press.

Hacking, I. (1999). The social construction of what? Cambridge, MA: Harvard University Press.

Hakken, D. (1999).Cyborgs@cyberspace?: An ethnographer looks at the future. New York: Routledge.

Hakken, D. (2003). The knowledge landscapes of cyberspace. New York: Routledge.

Hakken, D. (2008). Cyberspace. In W. A. Darity (Ed.), International encyclopedia of the social sciences (Vol. 2, pp. 216-217). Detroit: Macmillan Reference USA.

Halperin, D. (1995). Saint Foucault: Towards a gay hagiography. New York: Oxford University Press.

Haraway, D. J. (1991). Simians, cyborgs, and women: The reinvention of nature. New York: Routledge.

Hayek, F. A. (1945). The uses of knowledge in society. American Economic Review, 35(4), 519-530.

Hayek, F. A. (1964). The theory of complex phenomena. In M. Bunge (Ed.), The critical approach to science and philosophy (pp. 332-349). New York: The Free Press of Glencoe.

Hayek, F. A. (1967). Studies in philosophy, politics, and economics. Chicago: University of Chicago Press.

Hinshaw, V. G., Jr. (1943). The epistemological relevance of Mannheim's sociology of knowledge. Journal of Philosophy, 40(3), 57-72.

Hjørland, B. (2003). Fundamentals of knowledge organization. Knowledge Organization, 30(2), 87-111. 
Hjørland, B. (2013). Theories of knowledge organization - theories of knowledge. Knowledge Organization 40(3), 169-181.

Holtstein, J. A., \& Gubrium, J. F. (Eds.). (2008). Handbook of constructionist research. New York: The Guilford Press.

Horowitz, I. L. (1976). Philosophy, science, and the sociology of knowledge. Westport, CT: Greenwood Press. (Original work published 1961).

Huutoniemi, K. (2010). Evaluating interdisciplinary research. In R. Frodeman (Ed. in chief), The Oxford handbook of interdisciplinarity (pp. 309-320). Oxford: Oxford University Press.

Jantsch, E. (1972a). Technological planning and social futures. New York: John Wiley \& Sons.

Jantsch, E. (1972b). Towards interdisciplinarity and transdisciplinarity in education and innovation. In Centre for Educational Research and Innovation (CERI) (Ed.), Interdisciplinarity: Problems of teaching and research in universities (pp. 97-121). Paris: Organisation for Economic Cooperation and Development.

Jencks, C., \& Riesman, D. (1968). The academic revolution. Garden City, NY: Doubleday \& Company.

Kenway, J., Bullen, E., \& Fahey, J. with Rabb, S. (2006). Haunting the knowledge economy. Abington, Oxon, England: Routledge.

Kilov, H., \& Sack, I. (2005). Exploiting reusable abstractions in organizational inquiry: Why reinvent square wheels? In J. Courtney, D. B. Price, \& J. D. Haynes (Eds.), Inquiring organizations: Moving from knowledge management to wisdom (pp. 337-359). Hershey, PA: Idea Group Publishing.

Kirp, D. L. (2003). Shakespeare, Einstein, and the bottom line: The marketing of higher education. Cambridge, MA: Harvard University Press.

Klein, J. T. (1996). Crossing boundaries: Knowledge, disciplinarities, and interdisciplinarities. Charlottesville: University Press of Virginia.

Klein, J. T. (2000a). Integration, evaluation, and disciplinarity. In M. A. Somerville \& D. J. Rapport (Eds.), Transdisciplinarity: Recreating integrated knowledge (pp. 49-59). Montreal: McGill-Queen's University Press.

Klein, J. T. (2000b). Voices of Royaumont. In M. A. Somerville \& D. J. Rapport (Eds.), Transdisciplinarity: Recreating integrated knowledge (pp. 3-13). Montreal: McGill-Queen's University Press.

Klein, J. T. (2009). The rhetoric of interdisciplinarity: Boundary work in the construction of new knowledge. In A. A. Lunsford (Ed.), The Sage handbook of rhetorical studies (pp. 263-283). Thousand Oaks, CA: Sage.

Klein, J. T. (2010). A taxonomy of interdisciplinarity. In R. Frodeman (Ed. in chief), The Oxford handbook of interdisciplinarity (pp. 15-30). Oxford: Oxford University Press.

Kline, S. J. (1995). Conceptual foundations for multidisciplinary thinking. Stanford, CA: Stanford University Press.

Kochen, M. (1974). Principles of information retrieval. Los Angeles: Melville Publishing Company.

Kornblith, H. (1994). Introduction: What is naturalistic epistemology? In H. Kornblith (Ed.), Naturalizing epistemology (pp. 1-14). Cambridge, MA: MIT Press.

Lankes, R. D. (2011). The atlas of new librarianship. Cambridge, MA: MIT Press.

Latour, B., \& Woolgar, S. (1986). Laboratory life: The construction of scientific facts. Princeton, NJ: Princeton University Press. (Original work published 1979).

Leary, L. (Ed.) (1955). The unity of knowledge. Garden City, NY: Doubleday.

Lehrer, K. (1990). Theory of knowledge. Boulder, CO: Westview. 
López-Huertas, M. (2013). Reflexions on multidimensional knowledge: Its influence on the foundation of knowledge organization. Knowledge Organization, 40(6), 400-407.

Losee, R. M. (2014). Information and knowledge: Combining justification, truth, and belief. Informing Science: The International Journal of an Emerging Transdiscipline, 17, 75-93. Retrieved from http://www.inform.nu/Articles/Vol17/ISJv17p075-093Losee0495.pdf

Lotman, J. (2005). On the semiosphere (W. Clark, Trans.). Sign Systems Studies, 33(1), 205-228. (Original work published 1984).

Lotman, J. (2009). Culture and explosion (M. Grishakova, Ed.; W. Clark, Trans.). Berlin: Mouton de Gruyter.

Lucey, K. G. (Ed.). (1996). On knowing and the known: Introductory readings in epistemology. Amherst, NY: Prometheus Books.

Lyotard, F. (1984). The postmodern condition: A report on knowledge (G. Bennington \& B. Massumi, Trans.) Minneapolis: University of Minnesota Press. (Original work published 1979).

Machlup, F. (1962). The production and distribution of knowledge in the United States. Princeton, NJ: Princeton University Press.

Machlup, F. (1980-1984). Knowledge: Its creation, distribution, and economic significance (Vols. 1-3). Princeton, NJ: Princeton University Press.

Machlup, F. (1980). Knowledge and knowledge production. Princeton, NJ: Princeton University Press.

Machlup, F. (1982). The branches of learning. Princeton, NJ: Princeton University Press.

Machlup, F. (1983). Semantic quirks in the study of information. In F. Machlup \& U. Mansfield (Eds.), The study of information: Interdisciplinary messages (pp. 641-672). New York: John Wiley \& Sons.

Machlup, F. (1984). The economics of information and human capital. Princeton, NJ: Princeton University Press.

Machlup, F., \& Leeson, K. (1978-1980). Information through the printed word: The dissemination of scholarly, scientific, and intellectual knowledge (Vols. 1-4). New York: Praeger.

Machlup, F., \& Mansfield, U. (Eds.). (1983). The study of information: Interdisciplinary messages. New York: John Wiley \& Sons.

Madni, A. M. (2007). Transdisciplinarity: Reaching beyond disciplines to find connections. Transactions of the Society for Design and Process Science 11(1), 1-11.

Maquet, J. J. (1951). The sociology of knowledge: Its structure and its relation to the philosophy of knowledge: A critical analysis of the systems of Karl Mannheim and Pitrim A. Sorokin (J. F. Locke, Trans.). Boston: Beacon Press. (Original work published 1949).

Martin, B. (2008). Knowledge management. Annual Review of Information Science \& Technology (ARIST) $42,371-424$.

Maslow, A. H. (1966). The psychology of science: A reconnaissance. Chicago: Henry Regnery Company.

McClelland, D. C. (1953). The achievement motive. New York: Appleton-Century-Crofts.

McInerney, C. (2002). Knowledge management and the dynamic nature of knowledge. Journal of the American Society for Information Science and Technology, 53(12), 1009-1016.

Merleau-Ponty, M. (1962). Phenomenology of perception (C. Smith, Trans.). London: Routledge and Kegan Paul. (Original work published 1945).

Messer-Davidow, E., Shumway, D. R., \& Sylvan, D. J. (Eds.). (1993). Knowledges: Historical and critical studies in disciplinarity. Charlottesville: University Press of Virginia.

Miksa, F. L. (1985). Machlup's categories of knowledge as a framework for viewing library and information science history. Journal of Library History, 20(2), 157-172. 
Miksa, F. L. (1998). The DDC, the universe of knowledge, and the post-modern library. Albany, NY: Forest Press.

Miller, T. (2012). Blow up the humanities. Philadelphia: Temple University Press.

Mourad, R. P. (1995). Postmodern philosophical critique and the pursuit of knowledge in higher education. Westport, CT: Bergin \& Garvey.

Murphy, W. F., Jr. (2011). The Informing Science Institute: The informing system of a transdiscipline. Informing Science: The International Journal of an Emerging Transdiscipline, 14, 91-123. Retrieved from http://www.inform.nu/Articles/Vol14/ISJv14p091-123Murphy598.pdf

Nicolescu, B. (2012). Transdisciplinarity: The hidden third between the subject and the object. Human and Social Studies, 1(1), 13-28.

Nitecki, J. Z. (1985). The concept of information - knowledge continuum: Implications for librarianship. Journal of Library History, 20(4), 387-407.

Nonaka, I., \& Takeuchi, H. (1995). The knowledge-creating company: How Japanese companies create the dynamics of innovation. New York: Oxford University Press.

Nowotny, H., Scott, P., \& Gibbons, M. (2001). Rethinking science: Knowledge and the public in an age of uncertainty. Cambridge, England: Polity Press.

Pelto, G., \& Pelto, P. (1997). Studying knowledge, culture, and behavior in applied medical anthropology. Medical Anthropology Quarterly (new series), 11(2), 147-163.

Pfaffenberger, B. (1992). The social anthropology of technology. Annual Review of Anthropology, 21, 491516.

Pfirman, S., \& Martin, P. J. S. (2010). Facilitating interdisciplinary scholars. In R. Frodeman (Ed. in chief), The Oxford handbook of interdisciplinarity (pp. 387-403). Oxford: Oxford University Press.

Polanyi, M. (1958). Personal knowledge: Towards a post-critical philosophy. Chicago: University of Chicago Press.

Polanyi, M. (1966). The tacit dimension. Garden City, NY: Doubleday.

Pop, I. G., \& Maties, V. (2008, May). A transdisciplinary approach to knowledge in mechatronical education. Paper presented at Mechatronics 2008, Le Grand-Bornand, France. Retrieved from https://www.academia.edu/3082313/Transdisciplinary_Approach_to_Knowledge_in_Mechatronical_E ducation

Pritchard, D. (2009). Knowledge. Houndsmills, Basingstoke, Hants, England: Palgrave Macmillan.

Rainie, L., \& Wellman, B. (2012). Networked: The new social operating system. Cambridge, MA: MIT Press.

Rayward, W. B. (1983). Library and information sciences: Disciplinary differentiation, competition, and convergence. In F. Machlup \& U. Mansfield (Eds.), The study of information: Interdisciplinary messages (pp. 343-363). New York: John Wiley \& Sons.

Readings, B. (1995). The university in ruins. Cambridge, MA: Harvard University Press.

Repko, A. F. (2012). Interdisciplinary research: Process and theory (2nd ed.). Thousand Oaks, CA: Sage.

Rice, R. E., McCreadie, M., \& Chang, S.-J. L. (2001). Accessing and browsing information and communication. Cambridge, MA: MIT Press.

Ross, D. (1979). The development of the social sciences. In A. Oleson \& J. Voss (Eds.), The organization of knowledge in modern America, 1860-1920 (pp. 107-138). Baltimore: Johns Hopkins University Press.

Roszak, T. (1994). The cult of information: A neo-Luddite treatise on high-tech, artificial intelligence, and the true art of thinking. Berkeley: University of California Press. 
Transdisciplinary Study of Knowledge

Saracevic, T. (1999). Information science. Journal of the American Society for Information Science, 50(12), 1051-1063.

Searle, J. R. (1995). The construction of social reality. New York: The Free Press.

Shannon, C. E., \& Weaver, W. (1949). The mathematical theory of communication. Urbana: University of Illinois Press.

Shera, J. (1961). Social epistemology, general semantics, and librarianship. Wilson Library Bulletin, 35, 767-770.

Shera, J. H. (1972). The foundations of education for librarianship. New York: Becker \& Hayes, Inc.

Shera, J. H. (1983). Librarianship and information science. In F. Machlup \& U. Mansfield (Eds.), The study of information: Interdisciplinary messages (pp. 379-388). New York: John Wiley \& Sons.

Shirky, C. (2010). Cognitive surplus: Creativity and generosity in a connected age. New York: Penguin Press.

Shoham, S. (2000). Library classification and browsing: The conjunction of readers and documents. Brighton, East Sussex, England: Sussex Academic Press.

Shumway, D. R. (2003). Disciplinary identities. In J. R. Di Leo (Ed.), Affiliations: Identity in academic culture (pp. 89-100). Lincoln: University of Nebraska Press.

Shumway, D. R., \& Messer-Davidow, E. (1991). Disciplinarity: An introduction. Poetics Today, 12(2), 201-225.

Sismondo, S. (1993). Some social constructions. Social Studies of Science, 23(3), 515-553.

Smiraglia, R. (2002). The progress of theory in knowledge organization. Library Trends, 50(3), 330-349.

Somerville, M. A., \& Rapport, D. J. (Eds.) (2000). Transdisciplinarity: Recreating integrated knowledge. Montreal: McGill-Queen's University Press.

Sowa, J. F. (1984). Conceptual structures: Information processing in mind and machine. Reading, MA: Addison-Wesley.

Spender, J. C. (1996). Making knowledge the basis of a dynamic theory of the firm. Strategic Management Journal, 17(winter special issue), 45-62.

Stenmark, D. (2001, Aug.). The relationship between information and knowledge. Proceedings of the IRIS 24, Ulvik, Norway. Retrieved from http://citeseerx.ist.psu.edu/viewdoc/download?doi=10.1.1.21.965\&rep=rep1\&type=pdf

Strijbos, S. (2010). Systems thinking. In R. Frodeman (Ed. in chief), The Oxford handbook of interdisciplinarity (pp. 453-470). Oxford: Oxford University Press.

Sunstein, C. (2008). Infotopia: How many minds produce knowledge. New York: Oxford University Press.

Taylor, M. C. (2001). The moment of complexity: Emerging network culture. Chicago: The University of Chicago Press.

Toffler, A. (1970). Future shock. New York: Random House.

Townley, C. T. (2001). Knowledge management and academic libraries. College \& Research Libraries $62(1), 44-55$.

Townsend, R. B. (2013). History's Babel: Scholarship, professionalization, and the historical enterprise in the United States, 1880-1940. Chicago: University of Chicago Press.

Turner, S. (2000). What are disciplines? And how is interdisciplinarity different? In P. Weingart \& N. Stehr (Eds.), Practising interdisciplinarity (pp. 46-65). Toronto: University of Toronto Press.

Ulin, D. L. 2010. The lost art of reading: Why books matter in a distracted time. Seattle: Sasquatch Books. 
Veysey, L. (1979). The plural worlds of the humanities. In A. Oleson \& J. Voss (Eds.), The organization of knowledge in America, 1860-1920 (pp. 51-106). Baltimore: Johns Hopkins University Press.

Wallace, D. P. (2007). Knowledge management: Historical and cross-disciplinary themes. Westport, CT: Libraries Unlimited.

Wallerstein, I. (2004). The uncertainties of knowledge. Philadelphia: Temple University Press.

Waters, L. (2004). Enemies of promise: Publishing, perishing, and the eclipse of scholarship. Chicago: Prickly Paradigm Press.

Weinberger, D. (2011). Too big to know: Rethinking knowledge now that the facts aren't the facts, experts are everywhere, and the smartest person in the room is the room. New York: Basic Books.

Wright, H. C. (1998). Jesse Shera, librarianship, and information science. Occasional research paper no. 5. Brigham Young University, School of Library and Information Sciences.

Zandonade, T. (2004). Social epistemology from Jesse Shera to Steve Fuller. Library Trends, 52(4), 810832.

Znaniecki, F. (1970). Sociology and the theory of knowledge. In J. E. Curtis \& J. W. Petras (Eds.), The sociology of knowledge: A reader (pp. 307-319). New York: Praeger. (Original work published 1940).

\section{Biography}

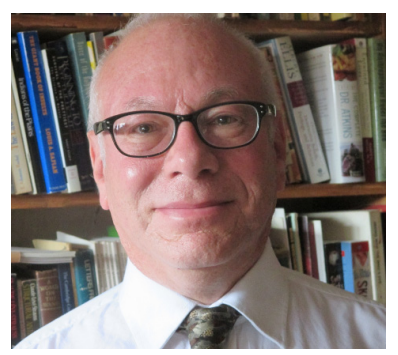

Jay Hillel Bernstein is Associate Professor and Reader Services Librarian in the Robert J. Kibbee Library at Kingsborough Community College of the City University of New York. He holds a Ph.D. in anthropology from the University of California, Berkeley and a Master of Library of Science from St. John's University, New York. He has conducted three years of ethnographic fieldwork in Indonesia and Brunei Darussalam focused on indigenous knowledge, cosmologies, and healing practices. He is the author of Spirits Captured in Stone: Shamanism and Traditional Medicine among the Taman of Borneo (Lynne Rienner, 1997) and many scholarly articles on topics ranging from the history of anthropology to the ethnobotany of the Bruneian rainforest to the distribution of holdings in library collections to film titles. He is pursuing his chief research interest in the study of theorization about knowledge, inquiry, and intellectual life across the disciplines by writing about concepts of knowledge in cultural anthropology. 